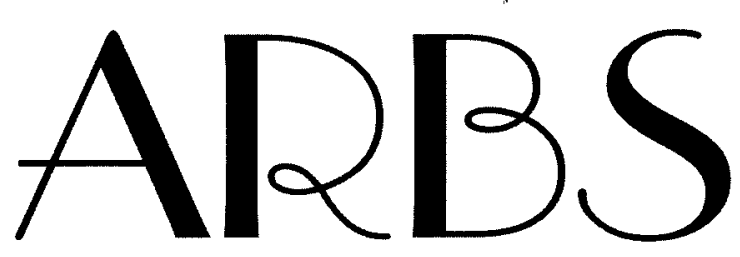

T NAGATA

Department of Anatomy and Cell Biology Shinshu University, JAPAN

\title{
Aging Changes of Macromolecular Synthesis in the Respiratory Organs as Revealed by Microscopic Radioautography
}

\section{Contents}

\author{
Abstract \\ Introduction \\ Methods for the Demonstration of Macromolecular Synthesis \\ Experimental Animals \\ Administration of Radioactive Compounds \\ Animal Treatment and Tissue Processing \\ Application of Radioautographic Emulsions to Specimens \\ Light microscopic wet-mounting radioautography \\ Electron microscopic wet-mounting radioautography \\ Light microscopic dry-mounting radioautography \\ Electron microscopic dry-mounting radioautography
}

The Macromolecular Synthesis of the Lung

The DNA Synthesis of the Pulmonary Cells

The RNA Synthesis of the Pulmonary Cells

The Protein Synthesis of the Pulmonary Cells

The Macromolecular Synthesis of the Trachea

The DNA Synthesis of the Tracheal Cells

The Glycoprotein Synthesis of the Tracheal Cells

Concluding Remarks

Acknowledgments

References

Correspondence

Professor Emeritus, Department of Anatomy and Cell Biology, Shinshu University School of Medicine, Matsumoto 390-8621, Japan.

Professor, Department of Anatomy and Physiology, Nagano Women's Jr. College,

Nagano 380-0803, Japan

Phone: +81-262-41-0308, FAX: +81-263-46-2848, E-mail: nagatas@po.cnet.ne.jp

Financial support: Ministry of Education, Science and Culture of Japanese Government as well as the Japan Foundation for Promotion of Private Schools. 


\section{Abstract}

For the purpose of elucidating the aging changes of macromolecular synthesis such as DNA, RNA, proteins, glucides and lipids in various organ systems of experimental animals and men, we have studied the respiratory organs of aging mice as a series of systematic studies using light and electron microscopic radioautography in various organ systems after incorporations with macromolecular precursors. The experimental animals mainly used were ddY strain mice at various aging groups from embryo to postnatal day 1 and 3, weeks 1 and 2, months $1,2,6$, 12 up to 2 year senescent stages. The animals were injected with such macromolecular precursors as ${ }^{3} \mathrm{H}$-thymidine for DNA, ${ }^{3} \mathrm{H}$-uridine for RNA, ${ }^{3} \mathrm{H}$-leucine for proteins, ${ }^{35} \mathrm{SO}_{4}$ for glycoproteins. The results demonstrated that these precursors were incorporated into various cell types in the lungs and tracheas at various ages from perinatal to juvenile, mature and senescent stages showing specific patterns of macromolecular synthesis. It is concluded that these specific pattern of macromolecular synthesis in respective cell types demonstrated the organ specificity of aging.

Key words: radioautography, DNA, RNA, proteins, lung, trachea, aging.

\section{Introduction}

In order to estimate aging changes of various organs of experimental animals and men, varieties of methodologies are now available including morphological, physiological and biochemical procedures. Among them, one of the good methods to demonstrate the sites of incorporations, syntheses and discharge and to estimate the quantities of synthesized molecules of various substances in animals should be microscopic radioautography. We have developed new techniques for both light and electron microscopic radioautography to localize intracellular sites of metabolism at cell organelle level by fixing tissues with chemical fixatives followed by conventional wet-mounting radioautography as well as to demonstrate soluble compounds by fixing tissues with cryo-fixation followed by dry-mounting radioautography in our laboratory during these 45 years. The localization of silver grains developed by means of ordinary radioautography demonstrates only the insoluble radioactive substances bound to the macromolecules fixed in the cell with the chemical fixatives used (Nagata, 1992, 1996, 1997ª 1998), while the radioisotopes bound to the small molecules which are not fixed with ordinary fixatives can be demonstrated by only cryo-fixation (Nagata, 1994). Ordinary radioautographic procedures can be designated as wet mounting radioautography, since the tissues are processed through both conventional wet treatments and applying wet radioautographic emulsions to the specimens (Nagata, 1992, 1996, 1997 a, $1998^{\text {a). }}$ In order to demonstrate any soluble radioactive compounds, special techniques are required in accordance with the characteristics of the radioisotopes used for 
radioautography (Nagata, 1994; Nagata \& Murata, 1977). We have developed novel techniques to demonstrate both soluble and insoluble radiolabeled compounds in cells and tissues at light and electron microscopic levels and then applied these methodologies to various organ systems of experimental animals during aging, from embryo to postnatal juvenile, mature and senescent stages, using radiolabeled precursors for macromolecular synthesis. We have reported the aging changes of macromolecular synthesis in some organ systems of mice by means of light and electron microscopic radioautography. The aging changes of DNA synthesis in the locomotive system such as the bone (Nagata, 1998') and the skeletal muscles (Hayashi \& Nagata, 1993), digestive system such as the salivary glands (Nagata et al., 2000), the esophagus (Duan et al., 1993), the intestines (Morita et al., 1993; Jin, 1995; Jin \& Nagata, 1995 a,b), the liver (Ma \& Nagata, 1988), the pancreas (Nagata \& Usuda, 1986), the endocrine system such as adrenal glands (Ito, 1995; Ito \& Nagata, 1996), the Leydig cells (Gao et al., 1993; 1995 (Hanai, 1993; Hanai et al., 1993) the reproductive system such as the testis (Gao, 1993; Gao et al., 1994) and the ovary, oviduct and uterus (Yamada \& Nagata, 1992 ; Li, 1994; Li \& Nagata, 1995), the circulatory system such as the blood cells (Murata et al., 1977, 1978) and the spleen (Olea \& Nagata, 1992a), the nervous system such as the cerebellum (Cui, 1995), and the sensory system such as the retina (Gao et al., 1992 a,b; Kong, 1992; Kong et al., 1992a; Kong \& Nagata, 1994; Gunarso et al.,1997) and the skin (Nagata, 1998'), RNA synthesis in the liver (Ma \& Nagata, 1990), the pancreas (Nagata et al., 1984; Nagata \& Usuda, 1986), the adrenal glands (Liang, 1998; Liang et al. 1999), the kidney (Hanai \& Nagata, 1994 a,b), the testis (Gao, 1993), the ovary, oviduct and uterus (Yamada \& Nagata, 1992 ; Li \& Nagata, 1995), the spleen (Olea \& Nagata, 1992 ), the retina (Kong et al., 1992 ${ }^{\mathrm{b}}$; Gunarso et al., 1996), the protein synthesis in the liver (Ma et al., 1991; Ma \& Nagata, 2000), the pancreas (Nagata, 2000 ), the testis (Gao, 1993), the uterus (Yamada, 1993), the retina (Toriyama, 1995), the cornea (Cui et al., 2000), glucides and sulfomucins in the blood cells (Murata et al., 1979), the intestines (Morita, 1993; Nagata \& Kawahara, 1999; Nagata et al., 1999), the pancreas (Nagata et al., 1992), the trachea (Nagata, 2000') and the kidney (Johkura, 1996; Johkura et al., 1996) and the ovary (Li et al., 1992), lipid synthesis in the pancreas (Nagata et al., 1988, 1990) were already reported. We have reviewed those results on several organs systems (Nagata, 1997a 1998 1999) or single organ system such as the digestive system (Nagata, 1995a) and the endocrine system (Nagata et al., 2000 ).

This paper reviews the results obtained from the respiratory organs, especially the lung and the trachea in our laboratory as a series of systematic studies (Nagata, 1997 ${ }^{\mathrm{a}}, 1998^{\mathrm{b}}, 1999,2001^{\mathrm{a}}$ ) during these 10 years. 


\section{Methods for the Demonstration of Macromolecular Synthesis}

We have developed useful techniques for both light and electron microscopic radioautography to localize intracellular sites of metabolism at cell organelle level by fixing tissues with chemical fixatives followed by conventional wetmounting radioautography as well as to demonstrate soluble compounds by fixing tissues with cryo-fixation followed by dry-mounting radioautography after administration of precursors for macromolecular compounds such as ${ }^{3} \mathrm{H}$-thymidine for DNA, ${ }^{3} \mathrm{H}$-uridine for RNA, ${ }^{3} \mathrm{H}$-amino acids for proteins, ${ }^{3} \mathrm{H}$-glucosamine for glucides, radio sulfate ${ }^{35} \mathrm{SO}_{4}$ for glycoproteins, ${ }^{3} \mathrm{H}$-glycerol and ${ }^{3} \mathrm{H}$-fatty acids for lipids (Nagata, $\left.1992,1994,1996,1997^{\mathrm{a}}, 1998^{\mathrm{a}}\right)$. The methods were applied to study the macromolecular synthesis of the respiratory organs in several groups of aging mice from fetal stage to postnatal stages from development to senescence. The respiratory system consists of both the lung and the respiratory tracts, which consist of the nose, the larynx and the trachea. In the respiratory organs of experimental animals, we have studied macromolecular synthesis in the lungs and the tracheas of ddY strain mice and salamanders at various ages.

\section{Experimental Animals}

As experimental animals we used strain ddY mice, which were maintained and bred, in our laboratory. One hundred and sixty-five ddY strain mice of both sexes in 55 aging groups each consisting of 3 litter animals of both sexes respectively, from fetal day 16 and 18, postnatal newborns at day 1 and 3, juvenile at week 1 and 2 , adults at month 1, 2, 6, 12 and 22, were used for the experiments. They were bred in our laboratory and were housed under conventional conditions, fed with normal mice chow (Clea CE2, Tokyo, Japan) with access to water ad libitum. The embryonic age was based on observation of the vaginal plug of the female mice (vaginal plug = day 0). As a supplementary experiment, we also used salamanders at 5 stages of aging from larvae ( 2 month after fertilization), juvenile ( 1 month), young adult (10 months after metamorphosis), mature adult (12 months after metamorphosis) to senescence ( 5 years), each consisting of 3 individuals of both sexes. They were sacrificed at given time with pentobarbital sodium (Nembutal, Abbott Laboratories, Chicago, IL, USA) anesthesia and perfusing via the left ventricles of the hearts with $2.5 \%$ glutaraldehyde in $0.1 \mathrm{M}$ cacodylate buffer ( $\mathrm{pH} 7.2$ ) one hour after injections with radio labeled compounds for radioautography for demonstration of macromolecular compounds by wet-mounting radioautography (Nagata, 1996, 1997, $1998^{a}$ ). Some other animals were used for demonstration of soluble compounds by cryo-fixation and dry-mounting radioautography (Nagata, 1994, 1998 a). In addition to the mice as mammals, we used 5 groups of salamanders as one of the nonmammalian vertebrates at various ages from larvae ( 2 month after fertilization), juvenile ( 1 month after metamorphosis), young adult ( 10 months after metamorphosis), 
mature adult ( 12 months after metamorphosis) to senescence (5 years), each consisting of 3 individuals of both sexes.

\section{Administration of Radioactive Compounds}

For the purpose of localizing sites of incorporation of radioactive compounds in animal bodies, the compounds, which were labeled with specific RIs, were usually administered by injections given subcutaneously, intramuscularly, intravenously or intraperitoneally. We have injected the animals intraperitoneally with radioactive precursors for macromolecular syntheses at varying concentrations as 37-1850 $\mathrm{KBq}$ (1-50 $\mu \mathrm{Ci})$ / gram body weight for both LMRAG and EMRAG or 370$3700 \mathrm{KBq}(10-100 \mu \mathrm{Ci}) /$ g.b.w. depending on the characteristics of the compounds and RIs used. The RI-labeled precursors used in our experiments were ${ }^{3} \mathrm{H}$-thymidine (Amersham, England, specific activity $877 \mathrm{GBq} / \mathrm{mM}$ ) for DNA synthesis, ${ }^{3} \mathrm{H}$-uridine (Amersham, England, 1.11 TBq/mM) for RNA, ${ }^{3} \mathrm{H}-4,5$-leucine (Amersham, $1.04 \mathrm{TBq} /$ $\mathrm{mM}$ ) for proteins, ${ }^{35} \mathrm{~S}$-sulfuric acid (Amersham, $1.11 \mathrm{TBq} / \mathrm{mM}$ ) for mucosubstances.

Sometimes in vitro labeling were carried out for tissue blocks in media containing radioactive compounds at concentrations of $37-3700 \mathrm{KBq}(1-100 \mu \mathrm{Ci})$ per $\mathrm{ml}$ medium, using $\mathrm{CO}_{2}$ incubator under normal conditions at $37^{\circ} \mathrm{C}$ with $5 \% \mathrm{CO}_{2}$ in air for varying time intervals from several minutes up to several hours.

\section{Animal Treatment and Tissue Processing}

All the experimental animals such as mice were anesthetized by intraperitoneal injections with pentobarbital sodium (Nembutal, Abbott Laboratories, Chicago, Ill., USA), after administrations of radioactive compounds by intraperitoneal injections, and are sacrificed at given time, usually 1 hour after the RI administration by per fusing via the left ventricles of the hearts with $2.5 \%$ glutaraldehyde in $0.1 \mathrm{M}$ cacodylate buffer at $\mathrm{pH} 7.2$, depending on whether insoluble or soluble radioautography will be carried out. For conventional insoluble radioautography the perfusion fixation can be used and the tissues from various organs were taken out, cut into small pieces ( $1 \times 1 \times 1 \mathrm{~mm})$, soaked in the same glutaraldehyde fixative at $4^{\circ} \mathrm{C}$ for 1 hour and post fixed in $1 \%$ osmium tetroxide in the same buffer for 1 hour, dehydrated with graded ethanol and embedded in epoxy resin (Epok 812, Oken Co., Tokyo, Japan). On the other hand, in vitro labeling of cultured cells and tissue blocks obtained from either animals or human biopsy materials were incubated in media (Eagle's MEM, Nissui, Tokyo, Japan) containing radioactive compounds, using $\mathrm{CO}_{2}$ incubator under normal conditions at $37^{\circ} \mathrm{C}$ for given time. They were then rinsed in Hanks' solution, fixed in the same buffered glutaraldehyde and osmium tetroxide solutions, dehydrated and embedded in epoxy resin as above. 
For the soluble radioautography, however, perfusion fixation cannot be used. The whole bodies of the small animals or organs and tissues taken out after decapitation without using any solution, should be immediately cryo-fixed by either metal contact method or immersion method cooled with liquid nitrogen and be processed by cryo-sectioning (Nagata \& Murata, 1977) or freeze-drying or freezesubstitution (Nagata, 1994).

Embedded tissues in epoxy resin can be used for either LMRAG or EMRAG. For LMRAG, thick sections at $2 \mu \mathrm{m}$ are cut on an ultramicrotome and picked up onto clean glass slides and warmed for extension and drying. For electron microscopy, ultrathin sections of $100 \mathrm{~nm}$ thickness are cut in general using a conventional transmission electron microscope with the accelerating voltage at 100 $\mathrm{kV}$. It is generally accepted that the thinner the section is the better the resolution, but the less the radioactivity it contains and the longer the exposure time for radioautography. If any intermediate high voltage electron microscope is available at such accelerating voltages as 200,300 or $400 \mathrm{kV}$, thicker sections at 200 or $400 \mathrm{~nm}$ thick can be used. We prefer to use semithin sections at $200 \mathrm{~nm}$ thicknesses at 400 $\mathrm{kV}$ in order to shorten the exposure time (Nagata, 1997 ). Semithin sections are cut on a Porter-Blum MT-2B ultramicrotome (Dupont-Sorvall, Newtown, CONN, USA). Ultramicrotomes of mechanical feeding type are preferable than thermal feeding type because of the accuracy of the section thickness, which effect on the number of silver grains by radioautography. Ultrathin or semithin sections are picked up onto either platinum or gold meshes in order to prevent the copper meshes from rusting through the histologic and radioautographic treatment especially by the development. Alternatively, collodion coated copper grid meshes can be used. For collodion coating, copper grid meshes (100-200 meshes) are soaked into $2 \%$ collodion solution for a few min, spread on a filter paper in a Petri dish and dried at $37^{\circ} \mathrm{C}$ for a few hours in an incubator.

We have developed simple routine standard techniques to demonstrate insoluble compounds in various cells and tissues of experimental animals and to quantify the contents of synthesized macromolecules in each cell and cell organelle by both light and electron microscopy. The localization of silver grains developed by means of ordinary radioautography, however, demonstrates only the insoluble radioactive substances bound to the macromolecules fixed in the cell with the chemical fixatives used (Nagata, 1992, 1996, 1997a , 1998ª). On the other hand, radioisotopes bound to the small molecules, which are not fixed with ordinary chemical fixatives, are washed away through conventional routine procedures such as fixation, dehydration, embedding, sectioning, and radioautographic procedures, so that these compounds cannot be demonstrated. Ordinary radioautographic procedures can be designated as wet-mounting radioautography, since the tissues are processed through both conventional wet treatments and applying wet radioautographic emulsions to 
the specimens. In order to demonstrate any soluble radioactive compounds, special techniques are required in accordance with the characteristics of the radioisotopes used for radioautography. By the cryo-fixation for dry-mounting radioautography, the labeled tissues are quickly frozen in a cooled liquid such as isopentane or propane cooled to its melting point with liquid nitrogen. Then the tissues can be cut by cryomicrotomy. At the light microscopic level, the frozen tissues can be cut in a cryostat at a thickness around 20-30 $\mu \mathrm{m}$ and the frozen sections are placed in contact with radioautographic emulsions by various techniques. Many papers have been published on this problem. We first used a large-wire loop to produce dry films, which were airdried and applied to cryostat sections placed on glass slides (Nagata \& Nawa, 1966). This procedure is very convenient and often used for demonstrating soluble compounds. At the electron microscopic level, however, only a few papers have been published on this principle, cryo-ultramicrotomy. A few authors (Appleton, 1964; Christensen, 1971) discussed the possibility of this method but they did not show any results, while we (Nagata et al., 1969) reported the results for the first time. To demonstrate soluble small molecular compounds, we employed cryo-fixation and dry-mounting radioautography for both LMRAG and EMRAG (Nagata, 1994).

The techniques for microscopic radioautography developed in our laboratory can be divided into 2 categories, i.e., wet-mounting radioautography for insoluble compounds such as macromolecular synthesis and dry-mounting radioautography for soluble compounds such as small molecular compounds, each can be sub-divided into 2 methods, respectively, light microscopy and electron microscopy (Nagata, 1997a $1998^{\mathrm{a}}$ ).

\section{Application of Radioautographic Emulsions to Specimens}

The nuclear emulsions used for radioautography are sensitive for radiation and consist of gelatin matrix and silver bromide crystals. The silver bromide crystals are uniform in size ranging from 70 to $400 \mathrm{~nm}$ in diameter depending on their brands produced by several photo-industry makers in the world such as Konica (Japan), Eastman-Kodak (USA), Ilford (UK). Several kinds of emulsions are commercially available in several countries. They are classified into four types, i. e., gel form or bulk liquid emulsions for light and electron microscopy, stripping films for LMRAG, coated plates or films for macro-RAG and LMRAG, and coated films for macro-RAG. We prefer to use bulk liquid emulsions produced by Konica Co. Tokyo, Japan, Konica NR-M2 for LMRAG and Konica NR-H2 for EMRAG, because of their fine grains and high sensitivity. Other types of emulsions such as Kodak NTB-2, 3, 5, or Ilford K-2 and L-4 can alternatively be used.

There are various techniques published for applying radioautographic emulsions to the specimens, depending on the kinds of specimens and radioactive 
compounds to examine. The procedures should be described in detail according to the methodologies employed in the following sections. After the specimens are made contact with the emulsions, they are kept in a cold $\left(4^{\circ} \mathrm{C}\right)$ dark room, usually in a light tight slide box kept in a refrigerator, for exposure for several weeks and finally developed. The development is a chemical reaction to reduce the silver bromide crystals in a developer and to convert them to metallic silver grains. When the emulsion is soaked in a developer, the developer reduces the silver bromide crystals, which contain specks of latent images building more and more metallic silver around the latent image. The size of silver grains depends on the constituents of the developer as well as the time and temperature of development. The standard developers such as Kodak D-19 or Konica SD-X1 consist of some reducing reagents such as methol and hydroquinone, which are abbreviated as MQ developers. When MQ developers are used for both LM and EMRAG, large spiral silver grains as long as a few $\mu \mathrm{m}$ are grown, which can be observed by light microscopy without problems but are toc large for electron microscopy. On the contrary, when a fine grain developer such as gold latensification and phenidone developer at a low temperature and shorter time is used, small dot-like silver grains less than $1 \mu \mathrm{m}$ in diameter are produced, which are preferable for electron microscopy (Nagata, 1992, 1996, 1997ª 1998 )

\section{Light microscopic wet-mounting radioautography}

For conventional light microscopic wet-mounting radioautography, the same tissue blocks for electron microscopy, which were fixed in buffered glutaraldehyde and osmium tetroxide solutions then embedded in epoxy resin, are cut on a Porter-Blum MT-2B ultramicrotome at $2 \mu \mathrm{m}$ thickness, picked up onto clean glass slides and warmed for extension and drying. Otherwise, conventional formalin fixed, paraffin embedded tissues can be used. In order to produce many radioautograms at once and also to compare each other quantitatively, the following procedures, which were developed in our laboratory (Nagata, 1992, 1997ª 1998 ${ }^{\mathrm{a}}$ ), are carried out.

A bottle of bulk emulsion (we use Konica NR-M2 emulsion, Konica Ltd., Tokyo, Japan), is melted in a water bath at $45^{\circ} \mathrm{C}$ for about 10 minutes, to which an equal amount of distilled water is added and mixed for 5-10 min. with a glass slide to remove all air bubbles (Fig. 1A). Then, a slide holder, made of stainless steal, holding 15 glass slides, which carry several thick sections, is dipped into the melted emulsion for several seconds, then they are pulled up vertically for about 3 seconds to assure equal thickness coating (3-4 $\mu \mathrm{m}$ ) over the sections (Fig. 1B). The faster the speed is, the thinner becomes the emulsion coating. The bottom of the slide holder is wiped with a paper towel to remove excess emulsion (Fig. 1C) and the slide holder is placed in an electric incubator at $28^{\circ} \mathrm{C}$ with humidity about $80 \%$, containing a wet sponge at the bottom, and dried for 1 hour. When the slides are dry, they are stored in a light 
tight slide box containing a desiccant (silica gel). After the edge of the box is sealed with black tape, it is kept in a refrigerator at $4^{\circ} \mathrm{C}$ for exposure (Fig. 1D). After an appropriate exposure time, all the slides are developed at once by pouring the developer into the slide box (Fig. 1E). We use Konica KD-X1 (formerly SD-X1) developer for Konica NR-M2 emulsion. Kodak D-19 may be used for any type of emulsions. After the development, the slides are rinsed in stop bath ( $2 \%$ aqueous acetic acid solution), fixed in a fixer ( $30 \%$ aqueous sodium thiosulphate solution) for 5 minutes twice, washed gently in running tap water for 10 minutes, and finally they are stained in $1 \%$ toluidine blue solution for light microscopy.
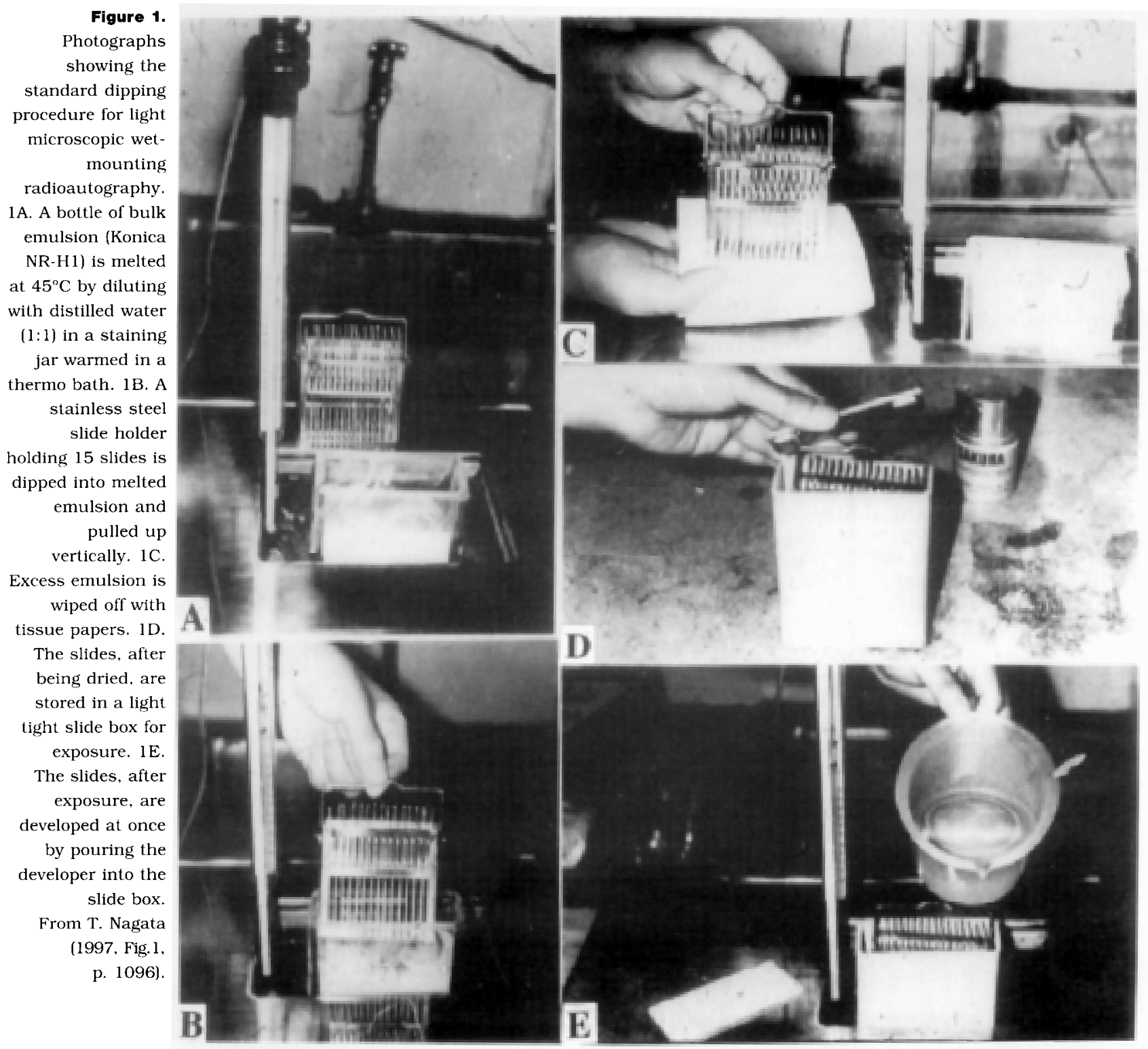

\section{Electron microscopic wet-mounting radioautography}

We used the same embedded tissues in epoxy resin for both LMRAG and EMRAG. For EMRAG, ultrathin sections at $0.1 \mu \mathrm{m}(100 \mathrm{~nm})$ or semithin sections at $0.2 \mu \mathrm{m}(200 \mathrm{~nm})$ are cut on an ultramicrotome and picked up on collodion coated grid meshes. The semi-thin sections should be observed by high voltage electron microscopy (Nagata, 1995 $, 1997^{\mathrm{b}}, 2001^{\mathrm{b}}$ ). 
As for the radioautographic emulsions, several types of emulsions are commercially available. We use Konica NR-H2 emulsion (Konica Ltd., Tokyo, Japan) because of the small sized silver bromide crystals and better sensitivity. To obtain thin monolayer of silver bromide crystals, two techniques, dipping and wire-loop methods, are now in general use. The choice lies between mounting the sections on a flat microscopic glass slide or on a grid mesh during the exposure. By the former method, glass slides are covered with thin collodion films on which sections are placed and they are coated with radioautographic emulsion by dipping similarly to the light microscopic procedure. After exposure and photographic processing, the sections and collodion films together with the emulsion are floated off the glass slide and picked up on a grid for examining by electron microscopy. This procedure is called a flat substrate method and practically very much complicated and troublesome. We do not prefer this method. On the other hand, by the latter method, sections are placed on grid meshes coated with collodion films according to the normal sectioning method and are covered with a preformed monolayer emulsion by picking up thin bubbles of molten emulsion on a wire-loop and allowing it to gel before touching it on the grids. This is called wire-loop method. We prefer this procedure, which was developed at our laboratory, using either small wire-loops or larger wire-loops; our procedure will be described in detail as follows (Nagata, 1992, 1996, 1997ª 1998 ${ }^{\mathrm{a}}$ ).

A regular square glass block, whose length of each side is $1.25 \mathrm{~cm}$, is made from the glass strips No. 4890-40 for LKB knife maker (LKB-Produkter AB, Bromma, Sweden). A square piece of double-coated Scotch tape, $4 \mathrm{~mm}$ in length, is stuck on the surface of each glass block. Six grids are placed around the tape like a rosette, arranged clockwise to identify each grid (Fig. 2A). The grids are vacuum coated with carbon at $10 \mathrm{~nm}$ thickness. Radioautographic emulsion is diluted equal part with distilled water at $45^{\circ} \mathrm{C}$. We use Konica NR-H2 emulsion from Konica (formerly Sakura) Ltd., Tokyo, Japan. Any other emulsions such as Kodak can alternatively be used. Ten $\mathrm{ml}$ of diluted emulsion is added with $0.2 \mathrm{ml}$ at $2 \%$ aqueous solution of dioctyl sodium sulfosuccinate (a surfactant) in order to prevent the emulsion film from bursting (Nagata et al., 1969; Nagata, 1996). A thin film of emulsion is obtained by dipping a wire-loop, $2.5 \mathrm{~cm}$ in diameter, which is made of platinum wire or vinyl coated iron wire (Fig. 2B). After air-drying horizontally for $1 \mathrm{~min}$, when the emulsion film is gelled but still wet, the film is applied to the grids on the glass block horizontally (Fig. 2C). The glass block is warmed at $28^{\circ} \mathrm{C}$ for 1 hour for drying the emulsion. For exposure, several glass blocks are attached to one side of a microscopic slide with double-coated Scotch tape (Fig. 2D). Control emulsion films should be checked by electron microscopy before the exposure (Fig. 2E). Several glass slides, carrying several glass blocks, respectively, are placed in a black light tight plastic slide box, which contains desiccant (silica gel), and the top is sealed with black tape (Fig. 2F). The slide box is kept in a refrigerator at $4^{\circ} \mathrm{C}$ for exposure. After an appropriate exposure 
time, the glass slides carrying glass blocks with grid meshes are processed for development, then stopped in stop bath, fixed in a fixer and stained with lead citrate solution for electron staining (Fig. 2G).

Concerning the development of the emulsions, when a conventional MQ-developer such as D-19 is used, long spiral silver grains are formed. In order to obtain smaller silver grains, phenidone developer after gold latensification (G-L) is recommended.

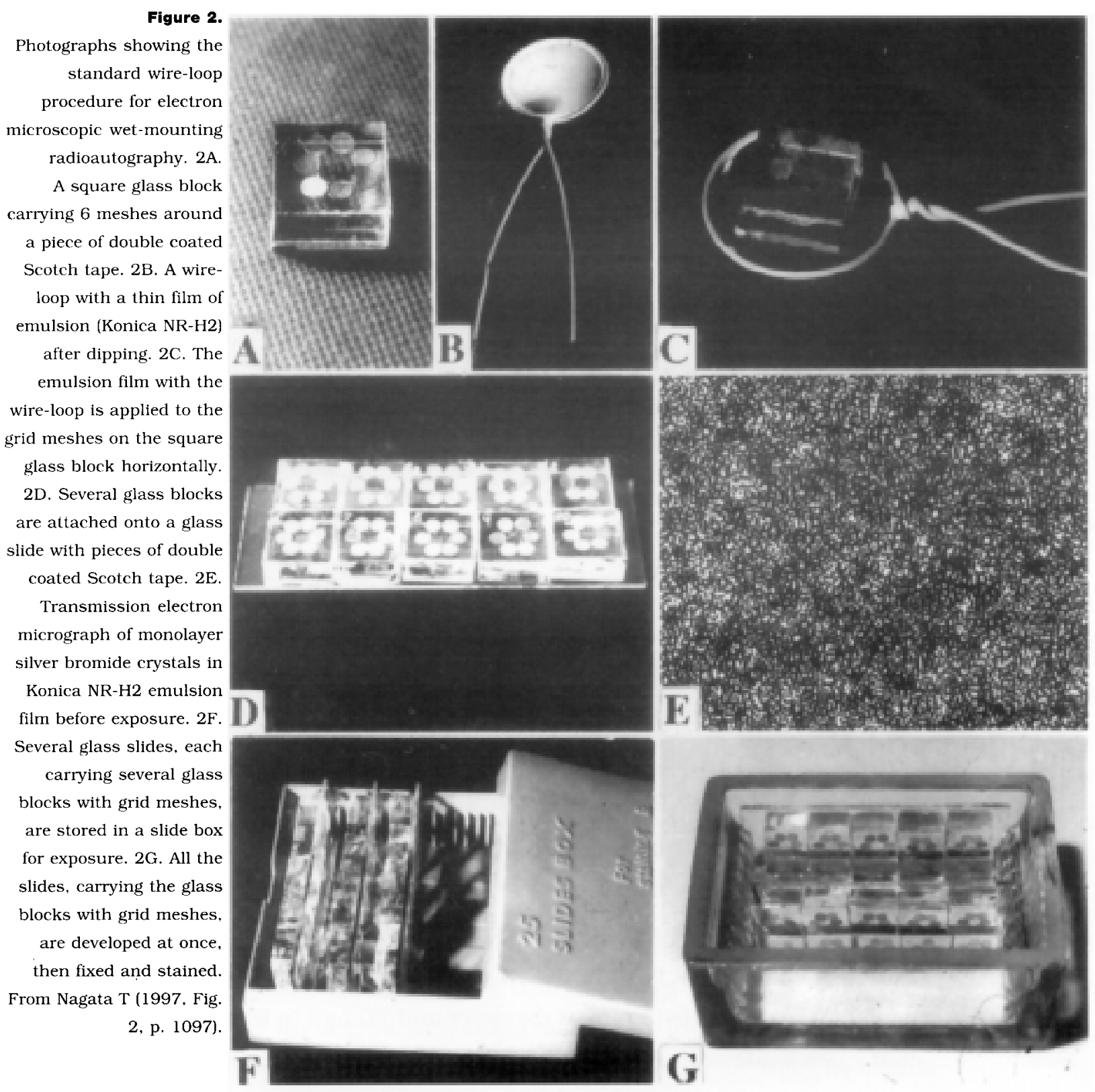

\section{Light microscopic dry-mounting radioautography}

Both cryo-sectioned and freeze-dried specimens and freeze-dried or freezesubstituted and embedded specimens should be coated with dry radioautographic emulsions without using any water. The procedure is designated as dry-mounting radioautography. The procedures for dry-mounting radioautography can be divided into two, light microscopic and electron microscopic. 
Historically various procedures were employed in the literature for light microscopic dry-mounting radioautography as described previously (Nagata, 1994, $\left.1997^{\mathrm{a}}, 1998^{\mathrm{a}}\right)$. Since the first application of cryostat sections on precoated slides at very low temperature, many authors recommended this technique at the light microscopic level. However, those procedures are very much complicated to treat both specimens and emulsions. We first used dry-films produced with a large wireloop, which were air-dried and applied to cryostat sections placed on glass slides (Nagata \& Nawa, 1966). We believe that this method is the most convenient one. Radioautographic emulsion is diluted equal part with distilled water at $45^{\circ} \mathrm{C}$. We use Konica NR-M2 emulsion from Konica (formerly Sakura) Ltd., Tokyo, Japan. Any other emulsions such as Kodak can alternatively be used. Ten $\mathrm{ml}$ of diluted emulsion are added with $0.2 \mathrm{ml}$ at $2 \%$ aqueous solution of dioctyl sodium sulfosuccinate (a surfactant) in order to prevent the emulsion film from bursting (Nagata \& Nawa, 1966). A thin film of emulsion is obtained by dipping a wire-loop, $2.5 \mathrm{~cm}$ in diameter, which is made of platinum wire or vinyl coated iron wire and set with a piece of Scotch tape on a glass slide as a handle. The handle is set horizontally on a flat desk for air-drying. After air-drying for 1-2 min., when the center of emulsion film is gelled and dried appearing transparent but the peripheral zone is still wet appearing opaque, the film is applied to the slide horizontally. The glass slide is kept in a Petri dish and warmed at $28^{\circ} \mathrm{C}$ in an incubator for 1 hour for drying the emulsion. After an appropriate exposure time, the glass slides are processed for development, then stopped in stop bath, fixed in a fixer and stained with toluidine blue solution for staining. Control tissues should be fixed with chemical fixative, dehydrated, embedded, wet-sectioned and wet-mounted by conventional dipping procedure.

\section{Electron microscopic dry-mounting radioautography}

For electron microscopic dry-mounting procedure, the grids carrying dry sections (either freeze-dried or freeze-substituted Epon embedded sections or freezesectioned and freeze-dried) are coated with carbon at 5-10 $\mathrm{nm}$ thick before emulsion application. They are then put on a grid holder made of a glass slide $(25 \mathrm{~mm} \times 75$ $\mathrm{mm}$ ) and 3 glass rods $(3 \mathrm{~mm}$ in diameter and $10 \mathrm{~mm}$ in length, respectively (Nagata et al., 1969). Radioautographic emulsion is diluted 1 part in 10 with distilled water at $45^{\circ} \mathrm{C}$ in the dark room. Ten $\mathrm{ml}$ of the diluted emulsion is added to $0.2 \mathrm{ml}$ of $2 \%$ aqueous solution of dioctyl sodium sulfosuccinate and is maintained at $45^{\circ} \mathrm{C}$ in a thermobath for several minutes to complete mixing: Dioctyl sodium sulfosuccinate, a surface activating agent is used to prevent the emulsion films from bursting while they are being dried in the air. We use Konica NR-H2 emulsion, produced by Konica Co., Ltd., Tokyo, Japan. Other emulsions for electron microscopic radioautography such as Kodak NTB or Ilford LA can be used in a similar way. A thin film of the 
emulsion thus prepared is obtained by dipping a platinum wire loop, about $1 \mathrm{~cm}$ in diameter, into the emulsion. Instead of a small platinum wire loop, a large vinyl coated iron wire loop, $2.5 \mathrm{~cm}$ in diameter, can also be used (Nagata, 1996, 1998). The handle of the wire loop is set on a flat surface for air-drying (for 1-2 min). The films are almost $100 \%$ air-dried without breaking by use of dioctyl sodium sulfosuccinate solution. The dried films are then applied to the grids on the holders like quoits. The grids are then transferred into Petri dishes and are warmed at $37^{\circ} \mathrm{C}$ for 1 hour to help the films adhere to the grids. They are exposed, developed, fixed and stained simultaneously.

\section{The Macromolecular Synthesis of the Lung}

The respiratory organs consist of both the lung, which are the essential respiratory portion and the tube for airway, which is the conducting portion of air to the lung. We have studied the macromolecular synthesis of the lungs of the experimental animals mainly ddY strain mice and some salamanders which were either injected in vivo or tissue blocks incubated in vitro with such macromolecular precursors as ${ }^{3} \mathrm{H}$-thymidine for DNA, ${ }^{3} \mathrm{H}$-uridine for RNA and ${ }^{3} \mathrm{H}$-amino acids for proteins.

\section{The DNA Synthesis of the Pulmonary Cells}

The changes of DNA synthesis of the lungs of mice and salamanders at various ages were studied by LMRAG (Sun et al., 1994, 1995') and EMRAG (Sun et al., 1995 ). The lung tissues of aging ddY mice in 11 groups at various ages, each consisting of 3 litter mates, from fetal day 16 and 18, postnatal day 1 and 3, week 1 and 2, month $1,2,6,12$ and 22 , were labeled in vitro with ${ }^{3} \mathrm{H}$-thymidine and the labeling indices were analyzed. As the results, the lungs of the fetal stages at day 16 (Fig. 3A) and 18 (Fig. 3B) showed immature structure composed of cuboidal epithelial cells, endothelial and interstitial cells but no squamous epithelial cells. At these stages, many cuboidal epithelial cells, endothelial cells and interstitial cells were labeled with silver grains due to ${ }^{3} \mathrm{H}$-thymidine. On the postnatal day 1 , however, the structure of the alveoli was characterized by further development of the alveolarcapillary network with a double capillary system (Fig. 3C). The cellular composition of the alveolar epitheliums resembled that of the adult lung, with a mixed population of type 1 and type 2 epithelial cells. At this stage, all the cell types, i.e., type 1 cells (small or squamous alveolar cells), type 2 cells (septal or great alveolar cells), endothelial cells and interstitial cells, were labeled with silver grains. On the postnatal day 3 , the structure of the alveoli further developed and it was noted that the labeling of the type 1 epithelial cell increased (Fig. 3D). At postnatal day 7, the pulmonary tissues showed complete alveolar structure with single capillary system almost the 
same as the adult (Fig. 3E). From postnatal week 2 to month 22, the alveolar structure was complete and the number of labeled cells in respective cell types increased gradually (Fig. 3F). When the labeling indices of respective cell types in each aging group were calculated, it showed aging changes (Fig. 4). The labeling indices of type

Figure 3.

Light microscopic radioautograms of the mouse lung at various ages labeled with ${ }^{3} \mathrm{H}$-thymidine, showing localizations of silver grains over the labeled nuclei synthesizing DNA. 3A. The lung tissue of a mouse embryo at fetal day 16. Many cuboidal epithelial cells (arrows), interstitial cells (IT) and endothelial (ED) cells are labeled with silver grains. Magnification $x 1100$. 3B. The lung tissue of a mouse embryo at fetal day 18 . The alveolar epithelial cells, interstitial cells and endothelial cells are labeled. The numbers of labeled cells are fewer than those on fetal day 16 (Fig. 3A). x 1300. 3C. The lung

tissue of a newborn mouse at postnatal day 1 . The labeled type 1 epithelial cell (arrow head) and interstitial cells (IT) are observable. $x$ 1300. 3D. The lung tissue of a mouse at postnatal day

3. The labeled type 1 epithelial cells can be seen. Note an increase in the number of labeled cells than the postnatal day 1 (Fig. 3B). $x 1300$. 3E. The lung tissue of a mouse at postnatal week 1 .

Many labeled type 1 epithelial cells can be observed. $x 270.3 \mathrm{~F}$.

The lung tissue of a mouse at postnatal week 2 . The arrows show the labeled type 2 epithelial cells. $\times 530$. From Sun $L$ et al. (1995, Figs. 1-6, p. 853).

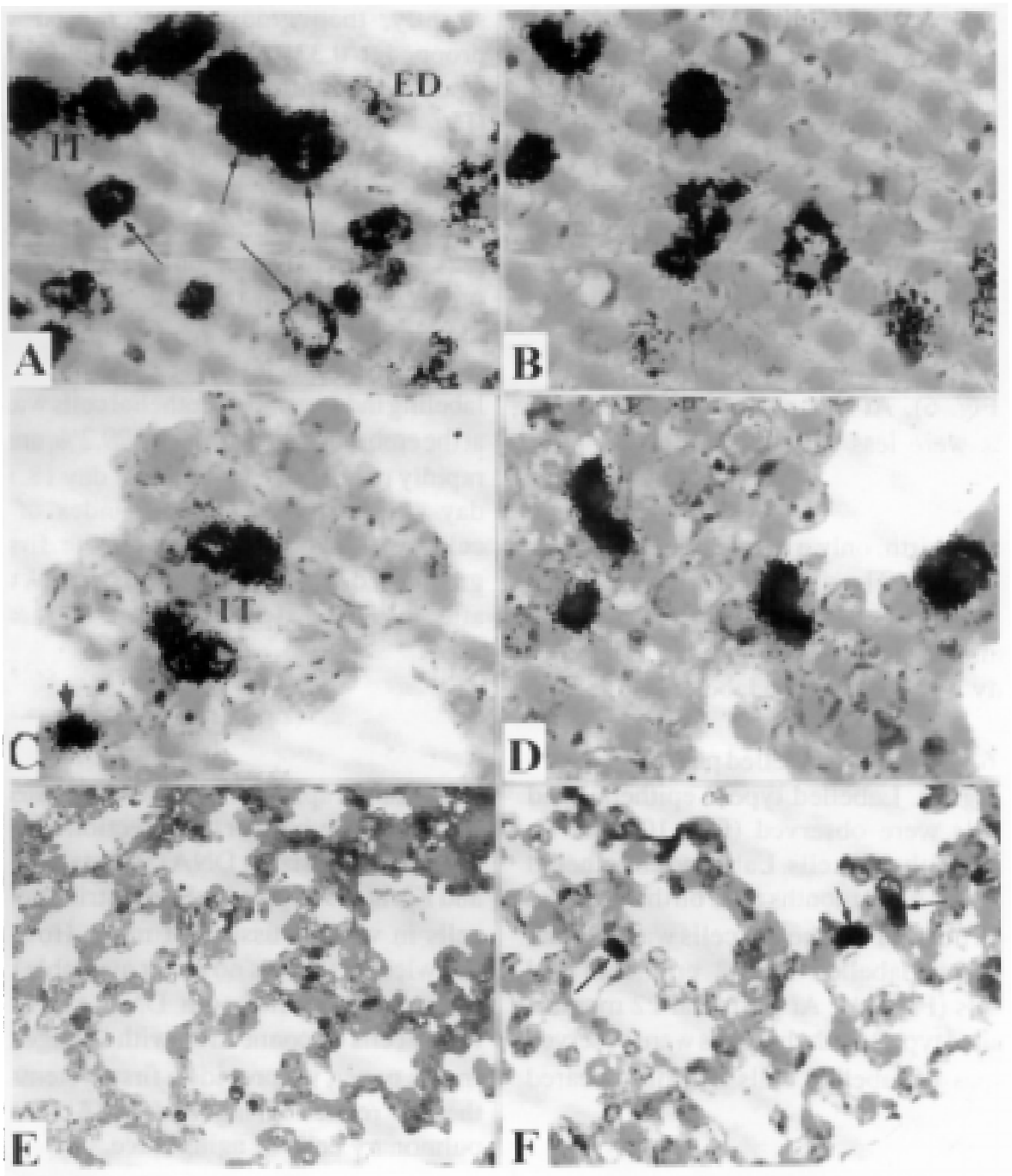

Histogram of the labeling indices of respective cell types of pulmonary cells in the mice at various ages from fetal day 16 to postnatal month 12 .

Mean \pm SD. From Sun L et al. (1995ª, Fig. 5, p. 132)

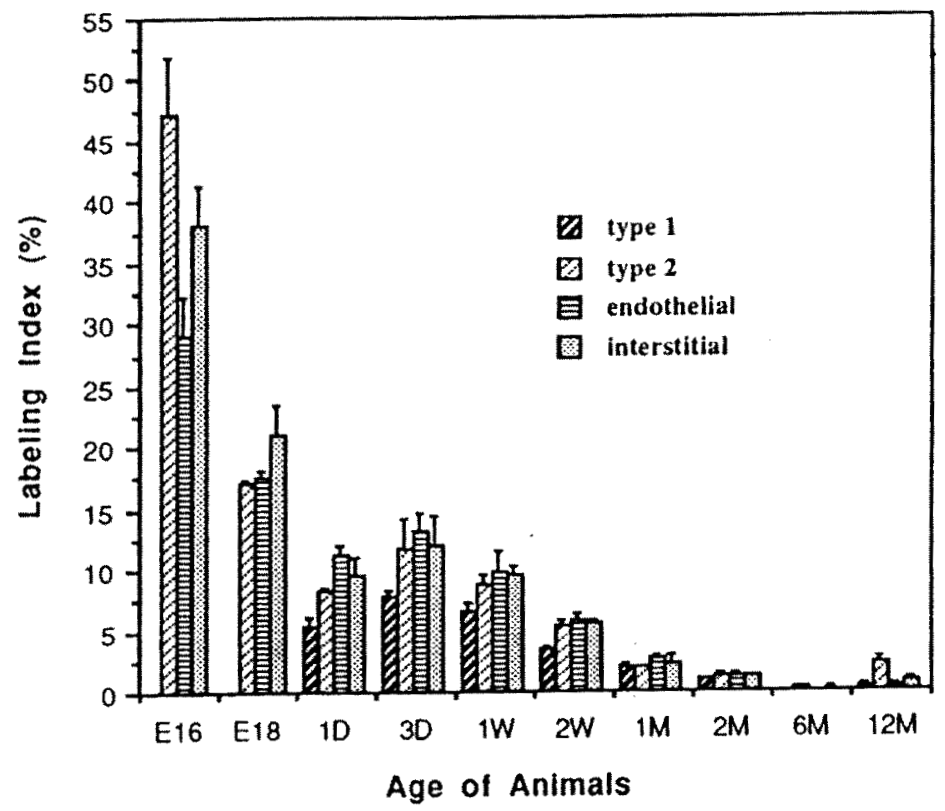


2 epithelial cells (47\%), interstitial cells (38\%), and endothelial cells $(29 \%)$ were found to peak at fetal day 18 and decreased at postnatal day 1 . Then, a second peak of type 2 epithelial cells appeared on postnatal day 3 , and finally the indices of all the cell types decreased with aging reaching almost 0 at postnatal month 6 . The results are different from the data of albino rats studied by O'Hare \& Townes (1970) who found an increase of labeled cells of type 1 and type 2 epithelia cells and interstitial cells on postnatal day 2 and 3.

On the other hand, inhalation experiment of ${ }^{3} \mathrm{H}$-thymidine by means of a nebulizer (Shinki type, Izumi Co., Suwa, Japan) into the lungs of 1 week old mice was carried out. After $45 \mathrm{~min}$ inhalation, the lung tissues were taken out and processed by either rapid-freezing and freeze-substitution for dry-mounting radioautography or conventional chemical fixation for wet-mounting radioautography. By wet-mounting RAG silver grains were observed in the nuclei of a few alveolar type 2 cells and interstitial cells, demonstrating DNA synthesis. By dry-mounting RAG numerous silver grains were located diffusely over all the epithelial cells, type 1 and type 2 , as well as the endothelial cells and interstitial cells, demonstrating soluble compounds (Duan et al., 1994). The results demonstrated that the RI-labeled compound inhaled from outside air into the lung could reach all the types of the alveolar cells.

The changes of DNA synthesis in the lungs of salamanders, as one of the no mammalian vertebrates, at 5 stages of aging from larvae ( 2 month after fertilization), juvenile ( 1 month after metamorphosis), young adult ( 10 months after metamorphosis), mature adult (12 months after metamorphosis) to senescence (5 years), each consisting of 3 individuals, were also studied by LMRAG after ${ }^{3} \mathrm{H}$-thymidine injection (Matsumura et al., 1994). The results showed that the labeling indices in the ciliated cells and mucous cells in the superficial layer were higher than those of the basal cells in the deep layer of the pulmonary epitheliums from larval and juvenile animals. They decreased and reached low level from young adults to senescent animals. These results demonstrated aging changes in salamanders.

\section{The RNA Synthesis of the Pulmonary Cells}

When the lung tissues of aging ddY mice in 11 groups at various ages, each consisting of 3 litter mates, from fetal day 16 and 18, postnatal day 1 and 3 , week 1 and 2 , month $1,2,6,12$ and 22 , were labeled in vitro with ${ }^{3} \mathrm{H}$-uridine and processed for LMRAG and EMRAG and analyzed (Sun, 1995). The RNA synthesis as demonstrated with silver grains due to ${ }^{3} \mathrm{H}$-uridine incorporations was observed in all cells, nuclei and cytoplasm, of all cell types, type 1 and type 2 epithelial cells, endothelial cells and interstitial cells, of the lungs at various ages from fetal day 16 (Fig. 5A), day 18 (Fig. 5B), postnatal newborn day 1 (Fig. 5C), day 3 (Fig. 5D), juvenile week 1 (Fig. 5E), week 2 (Fig. 5F), young adult month 1 (Fig. 5G), month 6 (Fig. 5H), and to senescent adult month 12 (Fig. 5I), month 22 (Fig. 5J). By quantitative analysis 
with grain counting, the number of silver grains changed with aging (Fig. 6). The grain counts in the nuclei and cytoplasm of type 1 epithelial cells, which could not be observed at prenatal stages, increased from the postnatal day 1 to day 3 and reachec a peak at week 1 , and decreased to month 22 (Fig. 6A). The grain counts in type 2 epithelial cells (Fig. 6B), interstitial cells (Fig. C) and endothelial cells (Fig. 6D) increasec from fetal day 16 to postnatal day 1,3 , and reached peaks at week 1 , then they decreased with aging. The results suggest that DNA synthesis, which played an active role in cell proliferation at prenatal stage, was ahead of RNA synthesis, which playec another role in cell differentiation and maturation at early postnatal stage from day 3 to 7 . Then, both activities, DNA and RNA syntheses, declined at the senescence.

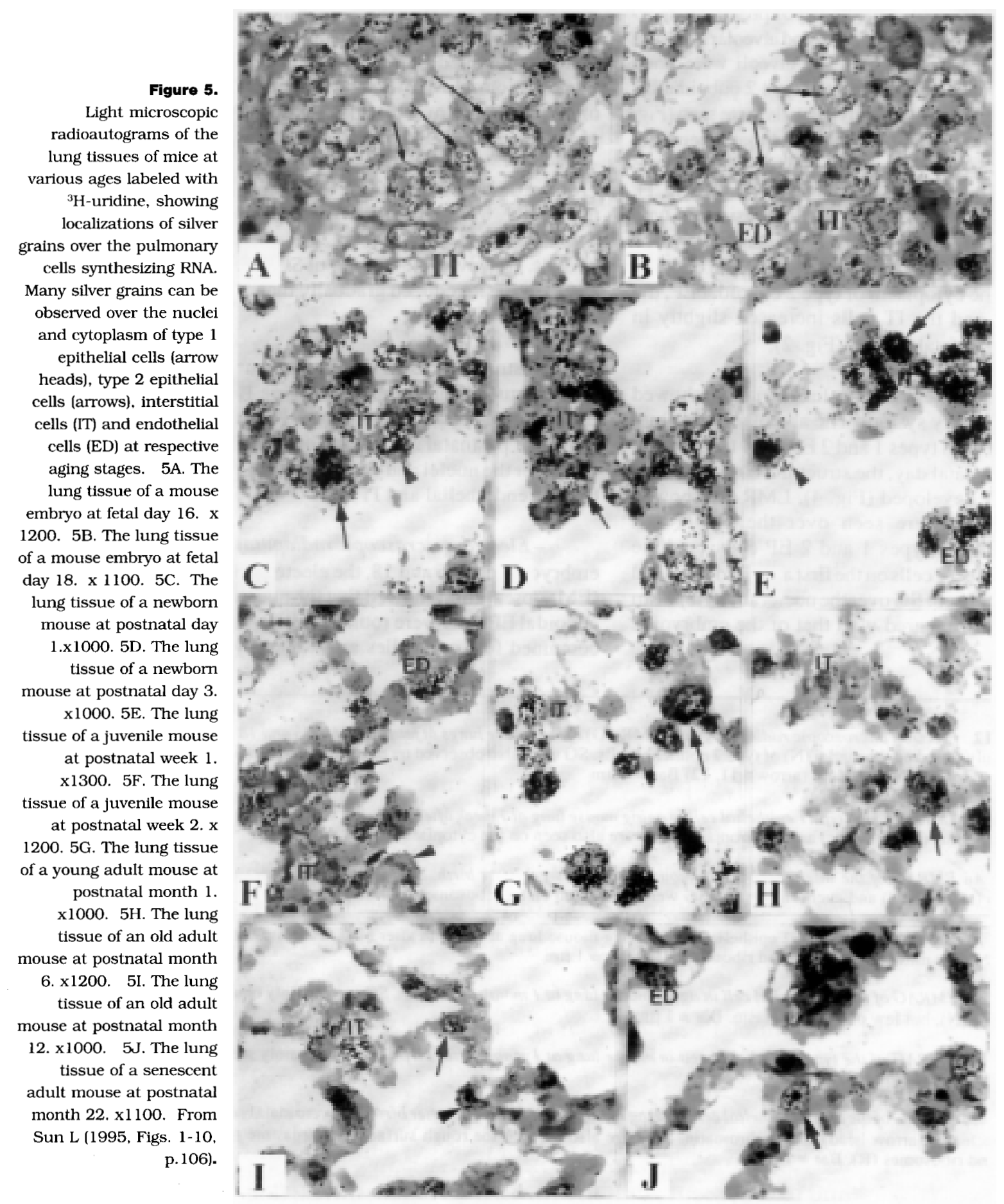



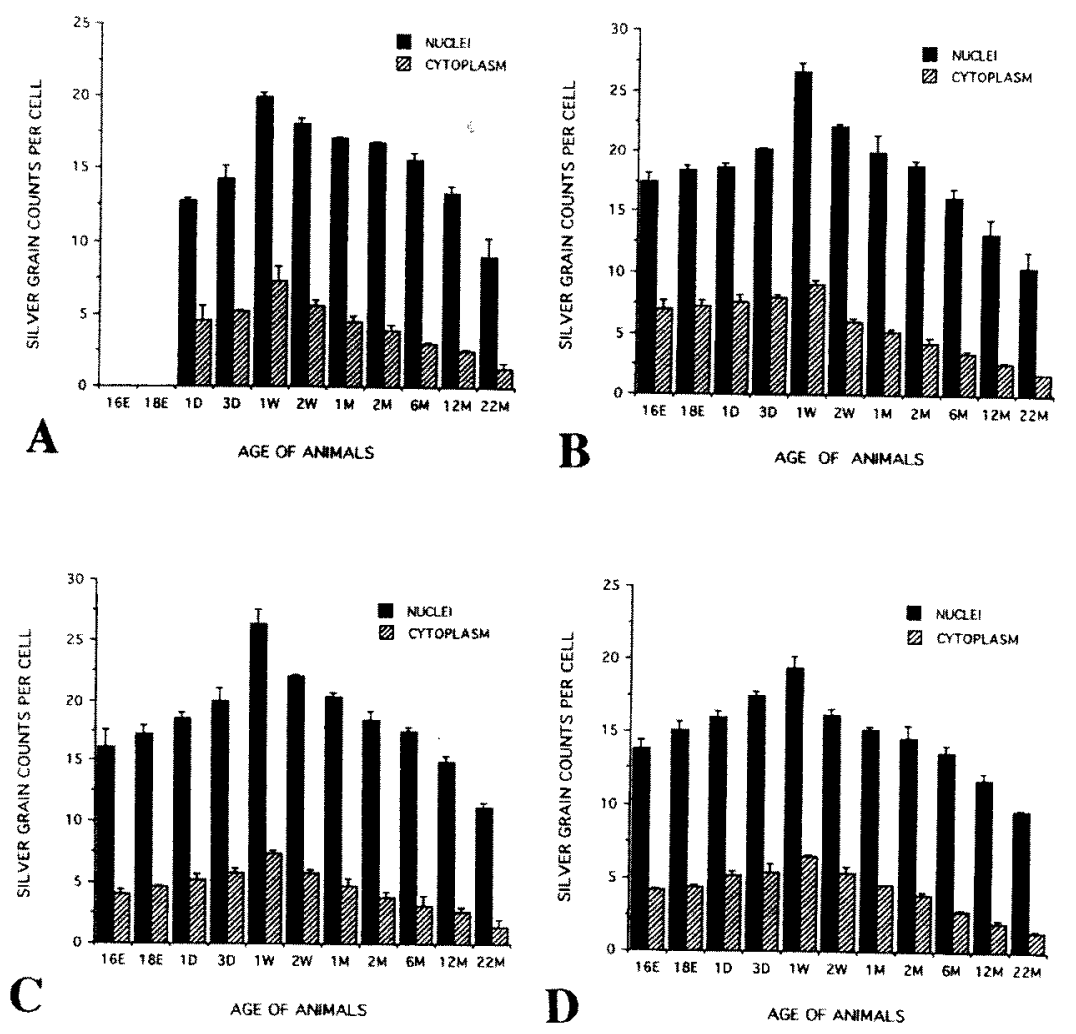

Figure 6. Histograms showing silver grain counts of respective cell types of the lung tissues of mice at various ages after labeling with ${ }^{3} \mathrm{H}$-uridine. Mean \pm S.D. 6A. The type 1 epithelial cells. $6 \mathrm{~B}$. The type 2 epithelial cells. $6 \mathrm{C}$. The interstitial cells. 6D. The endothelial cells. From Sun L (1995, Figs. 19-22, p. 1067).

\section{The Protein Synthesis of the Pulmonary Cells}

The protein synthesis of the lung tissues of aging mice in 10 groups at various ages, each consisting of 3 litter mates, from fetal day 16 and 18, postnatal day 1 and 3 , week 1 and 2, month $1,6,12$ and 22, were also studied by the incorporations of ${ }^{3} \mathrm{H}$-leucine (Sun et al., $1997^{\mathrm{b}}$ ). The lung tissues of the fetal animals at prenatal day 16 (Fig. 7A) and 18 (Fig. 7B) showed immature gland-like structure consisting of type 2 epithelial cells, endothelial cells and interstitial cells. All the nuclei and cytoplasm of these 3 types of cells were covered with many silver grains. At postnatal day 1, the lung tissues appeared primary saccules consisting of 4 types of cells, type 1 and type 2 epithelial cells, endothelial cells and interstitial cells (Fig. $7 \mathrm{C}$ ). Then, the alveolar structure developed to mature according to aging from day 3 (Fig. 7D), 7, 14 and month 1 , when the structure completed as adults. The number of silver grains observed over the type 1 epithelial cells, type 2 epithelial cells, interstitial cells and endothelial cells decreased after birth from postnatal day 1, 3 but increased at day 7 reaching a peak, and finally decreased to month 1, 6, 12 and 22 with aging (Fig.7). Comparing the grain counts between the karyoplasm and cytoplasm of respective cell types, type 1 epithelial cells (Fig. 8A), type 2 epithelial cells (Fig. 8B), interstitial cells (Fig. 8C), endothelial cells (Fig. 8D), at respective stages, the number of silver grains was more in the latter than the former, which meant that the proteins synthesized in cytoplasm for cell organelles were much more than the proteins 

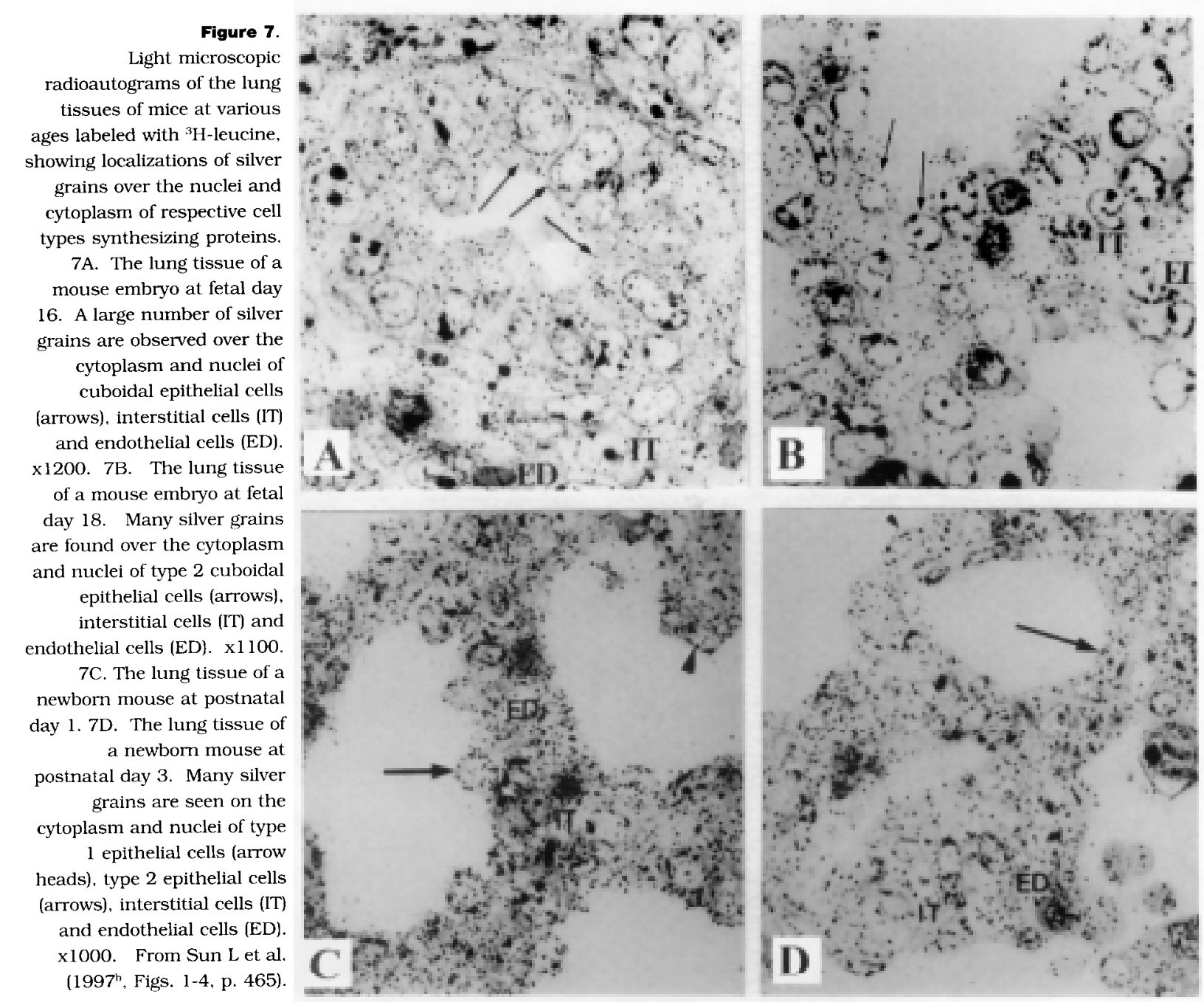

Figure 8.

Histogram showing the changes in silver grain counts of respective cells types type in aging mouse lungs labeled with ${ }^{3} \mathrm{H}$-leucine at various ages. Mean \pm SD. Significantly different from the prior age group on the cytoplasm (*) and nuclei () at $P<0.05$ using the Student's $t$ test. A. The

type 1 epithelial cells. B.The type 2 epithelial cells (cuboidal epithelial cells) $C$. The interstitial

cells. The endothelial cells. From Sun L et al.

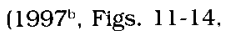
p. 467).

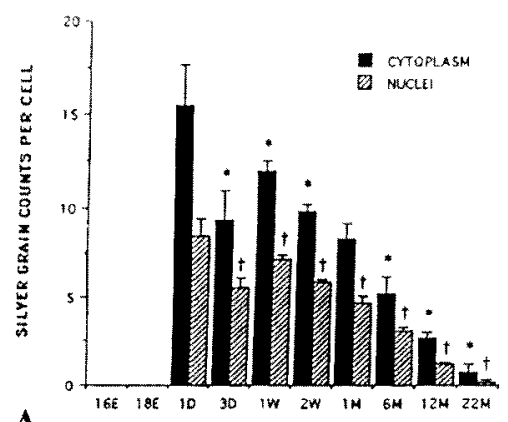

age of animals

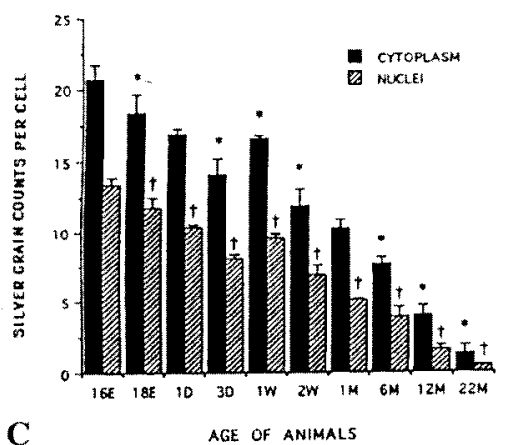

C

AGE OF ANIMALS

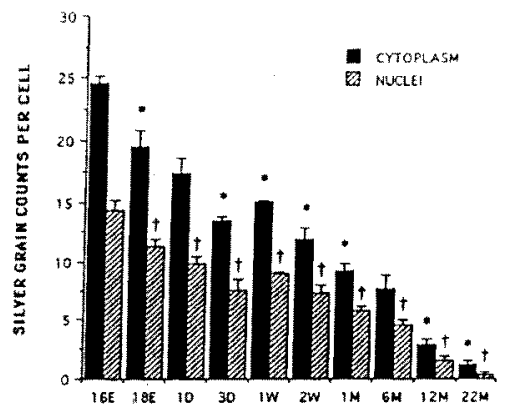

AGE OF ANIMALS

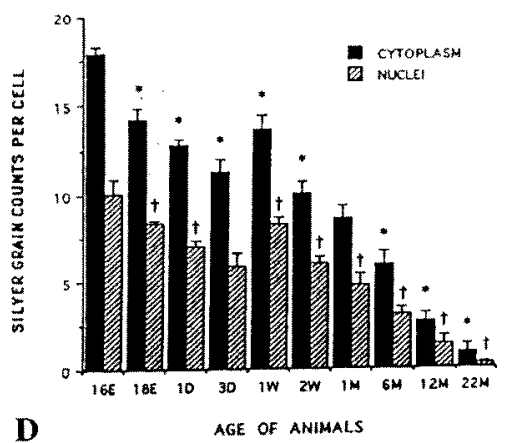


synthesized in karyoplasm for nucleoproteins. The results also suggested that both proteins in the karyoplasm and cytoplasm decreased once in early postnatal stage from day 1 to 3 and increased at postnatal day 7, then decreased again to senescence (Fig. 8A,B,C,D), which meant that the amount of proteins synthesized at fetal stage could be used for proliferation of cells because the labeling indices of respective cell types were at the maxima during the fetal stage, while the proteins synthesized at postnatal day 7 could be used for differentiation of the cells not for the proliferation because the amount of RNA synthesized in respective cell types peaked also at postnatal day 7 .

\section{The Macromolecular Synthesis of the Trachea}

The trachea is the main portion of the airway conducting air into the lung. We have studied the macromolecular synthesis of the experimental animals, which were injected with such macromolecular precursors as ${ }^{3} \mathrm{H}$-thymidine for DNA and radiosulfate ${ }^{35} \mathrm{SO}_{4}$ for glycoproteins.

\section{The DNA Synthesis of the Tracheal Cells}

The changes of DNA synthesis of tracheal cells in 8 groups of aging mice at various ages from fetal day 18, postnatal day 3,7, month 1, 2,6, 12 and 22, each consisting of 3 litter mates, were studied by LM and EMRAG after labeling with ${ }^{3} \mathrm{H}$ -

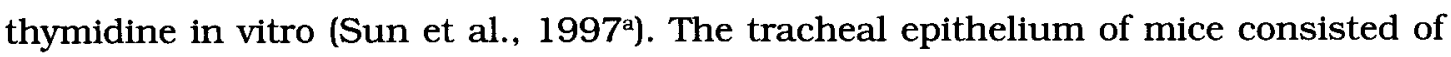
pseudostratified columnar epithelial cells, which can be classified into ciliated columnar cells, nonciliated columnar cells and basal cells, while the lamina propria mucosae consisted of fibroblasts with collagen fibers, smooth muscle cells, glandular cells and hyaline cartilage. At fetal day 18, the epithelial cells were immature and consisted of mostly nonciliated or basal cells but only small number of ciliated cells (Fig. 9A), while the lamina propria mucosae consisted of immature fibroblasts, glandular cells and chondrocytes (Fig. 9B). Among these cells, many nonciliated and basal cells in the epithelia as well as fibroblasts and chondrocytes were labeled with ${ }^{3} \mathrm{H}$-thymidine demonstrating DNA synthesis (Fig. 9A,B). On the postnatal day 3 , the structure of the tracheal rings further developed and some of the nonciliated cells, basal cells, chondrocytes, fibroblasts and smooth muscle cells were labeled but no ciliated cell was labeled (Fig. 9C,D,E). The number of labeled cells in respective cell types reduced remarkably at this stage as compared with those of the embryos. From postnatal week 1 to month $1,2,6,12$ and 22 , the structure of the tracheal ring further developed and differentiated (Fig. 9F), but the number of labeled cells in respective cell types decreased. By quantitative analysis, the labeling indices of respective cell types demonstrated that the DNA syntheses in the mouse tracheae changed due to aging (Fig. 10). The labeling indices revealed that the DNA syntheses of the non-ciliated and basal cells in the epithelium reached their maxima on fetal 


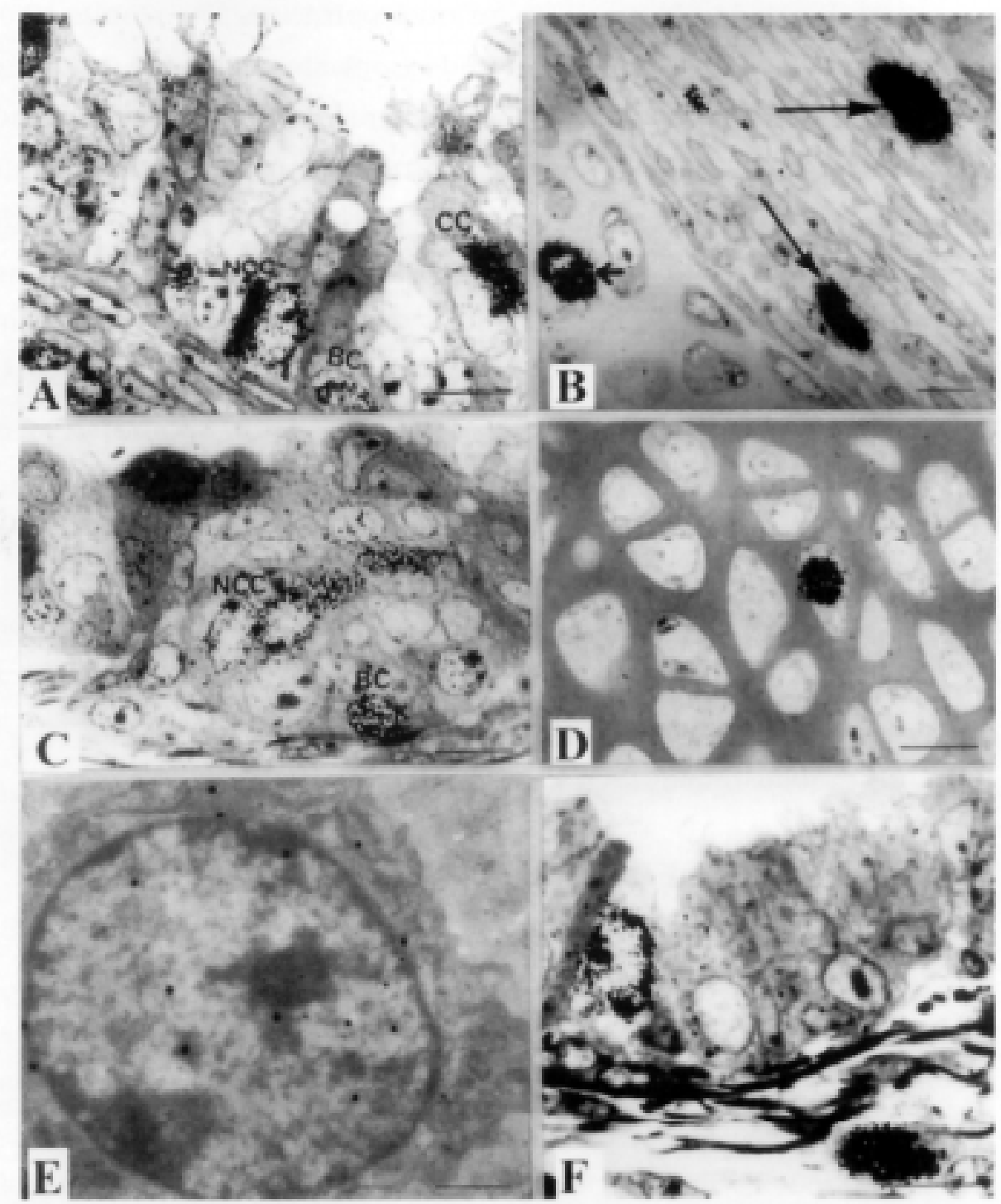

Flgure 9. Light and electron micrographic radioautograms of the tracheas of aging mice labeled with ${ }^{3} \mathrm{H}$-thymidine at various ages showing DNA synthesis. 9A. Low power magnification LMRAG of a mouse trachea at embryonic day 18 . Many nonciliated cells (NCC) and basal cells (BC) are labeled. A few labeled ciliated cells (CC) are seen. $x 1400$ (Scale bar $=10 \mu \mathrm{m})$. 9B. Low power magnification LMRAG of a mouse trachea at embryonic day 18. The labeled fibroblasts (arrows) and chondrocyte (arrow head) are seen. $\times 1000$ (Scale bar $=10 \mu \mathrm{m}$ ). $9 \mathrm{C}$. LMRAG of a mouse trachea at postnatal day 3 . The labeled nonciliated cells (NCC) and basal cells (BC) can be observed. The numbers of labeled cells are fewer than on fetal day 18 (Fig. 9A). $\mathrm{x} 1200$ (Scale bar $=10 \mu \mathrm{m}$ ). 9D. LMRAG of a mouse trachea at postnatal day 3. A chondrocyte is labeled. x1200 (Scale bar $=10 \mu \mathrm{m}$ ). 9E. An electron microscopic radioautogram (EMRAG) of a chondrocyte at postnatal day 3 . The silver grains are located mainly on the euchromatin in the nucleus. $x 12,000$ (Scale bar $=1 \mu \mathrm{m}$ ). 9F.LMRAG of a mouse trachea at postnatal week 1. A labeled nonciliated cell and a fibroblast can be observed, x1500 (Scale bar $=10 \mu \mathrm{m}$ ). From Sun L et al. (1997 Figs. 1-6, p. 214).

day 18, then fell down from postnatal day 3 to month 1 (Fig. 10A). The activity of DNA synthesis of ciliated cell was observed but very low in the fetal stage and the labeled ciliated cells disappeared at postnatal day 3 (Fig. 10A). It was supposed that the ciliated cell could not synthesize DNA and proliferate in the postnatal stages. Therefore, the ciliated cells are supposed to be derived by the division and transformation of basal cells and nonciliated cells (Sun et al., 1997'a). The basal cells may be the most important progenitor cells for nonciliated and ciliated cells in the tracheal epithelium.

On the other hand, the DNA synthesis of chondrocytes was the highest on embryonic day 18, and rapidly declined on postnatal day 3 , reaching zero at postnatal month 1 to 2 (Fig. 10B). The chondrocytes lost the ability of synthesizing 
Floure 10.

Histograms showing the labeling indices of respective cell types in the tracheal cells of the mice at various ages from fetal day 16 to postnatal month 22 . Mean \pm SD. 10A. The labeling indices of 3 types of tracheal epithelial cells, ciliated cells, nonciliated cells and basal cells. 10B. The labeling indices of chondrocytes of mice tracheae. 10C. The labeling indices of other cell types in the mouse tracheae. From Sun L et al. $\left(1997^{2}\right.$, Figs. 1315, p. 216).

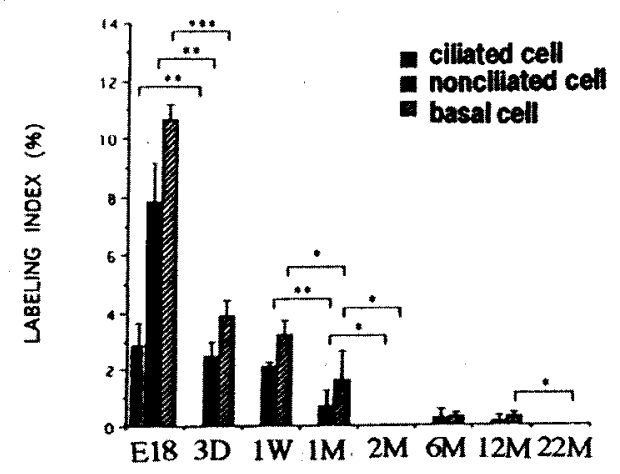

$\mathbf{A}$

AGE OF AMMALS
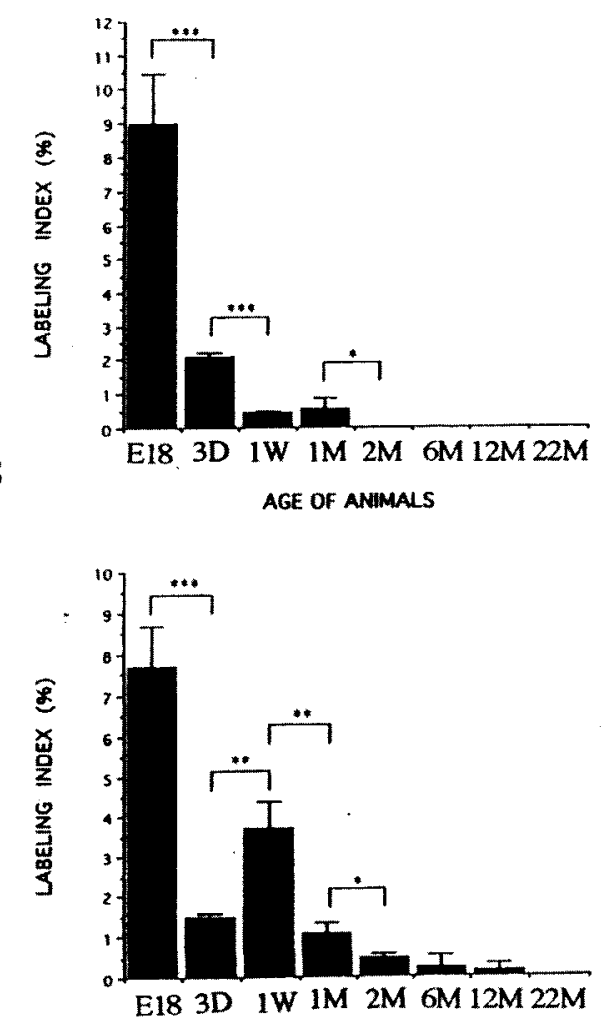

$\mathbf{C}$ AGE OF AMMMALS

DNA at 2 months after birth. The DNA syntheses of other cells, including fibroblasts, smooth muscle cells and glandular cells, were highest on fetal day 18 and fell markedly at postnatal day 3 , then decreased progressively due to aging (Fig. 10C). These results suggest that the growth and maturation activity of the chondrocytes and other connective tissues and smooth muscle cells attained their completion by postnatal month 1-2.

\section{The Glycoprotein Synthesis of the Tracheal Cells}

The incorporation of radiosulfate ${ }^{35} \mathrm{SO}_{4}$ into the tracheal cartilage showing glycoprotein synthesis in 9 groups of aging mice at various ages, prenatal day 19, postnatal day $1,3,7,14$, month 1,2, 6 and 12, was studied (Nagata, 2000'). Many 
silver grains were observed over the chondrocytes and extra cellular matrix of the tracheal cartilage in fetal and postnatal newborn mice (Fig. 11). The silver grains were mainly localized over the cartilage matrices both in the interterritorium and the territorium especially over the cartilage capsules surrounding the chondrocytes in the hyaline cartilage of perinatal stages from fetal day 19 (Fig. 11A) to postnatal day 1 (Fig. 11B). The grains were intensively localized in the inner layer of the cartilage at

Figure 11.

Light microscopic radioautograms of the hyaline cartilage of the tracheas of mice at various ages, showing radiosulfate incorporations synthesizing glycoproteins. 11A. The hyaline cartilage of the trachea of a mouse embryo at fetal day 19. Note that the numerous silver grains showing the incorporations of the radiosulfate accumulate over the interterritorial and territorial matrices but not so much over the chondrocytes. 11B. The hyaline cartilage of the trachea of a newborn mouse at postnatal day 1. Note that the number of silver grains accumulating over the interterritorial and territorial matrices decreased from the internal layer of the cartilage. 11C. The trachea of a newborn mouse at postnatal day 3 . Note that the number of silver grains accumulating over the interterritorial and territorial matrices decreased from the internal layer of the cartilage to

the external layer. Intense incorporation of the radiosulfate is observed disseminatedly over

several groups of cartilage capsules. 11D. The hyaline cartilage of the trachea of a newborn mouse at postnatal day 7. Note that the number of silver grains accumulating over the interterritorial and territorial matrices decreased from the internal layer of the cartilage to the external layer. Intense incorporations of the radiosulfate are observed disseminatedly over several groups of cartilage capsules in the external layer.

$11 \mathrm{E}$. The hyaline cartilage of the trachea of a juvenile mouse at postnatal day 14. Note that the silver grains disappeared from the internal layer of the cartilage. Less intense incorporations of the radiosulfate are observed disseminatedly over several groups of cartilage capsules in the external layer. Magnifications in

Figs. 1 1A-E are the same. $x 200$ (Scale bar $=50 \mu \mathrm{m})$. From Nagata $\mathrm{T}$

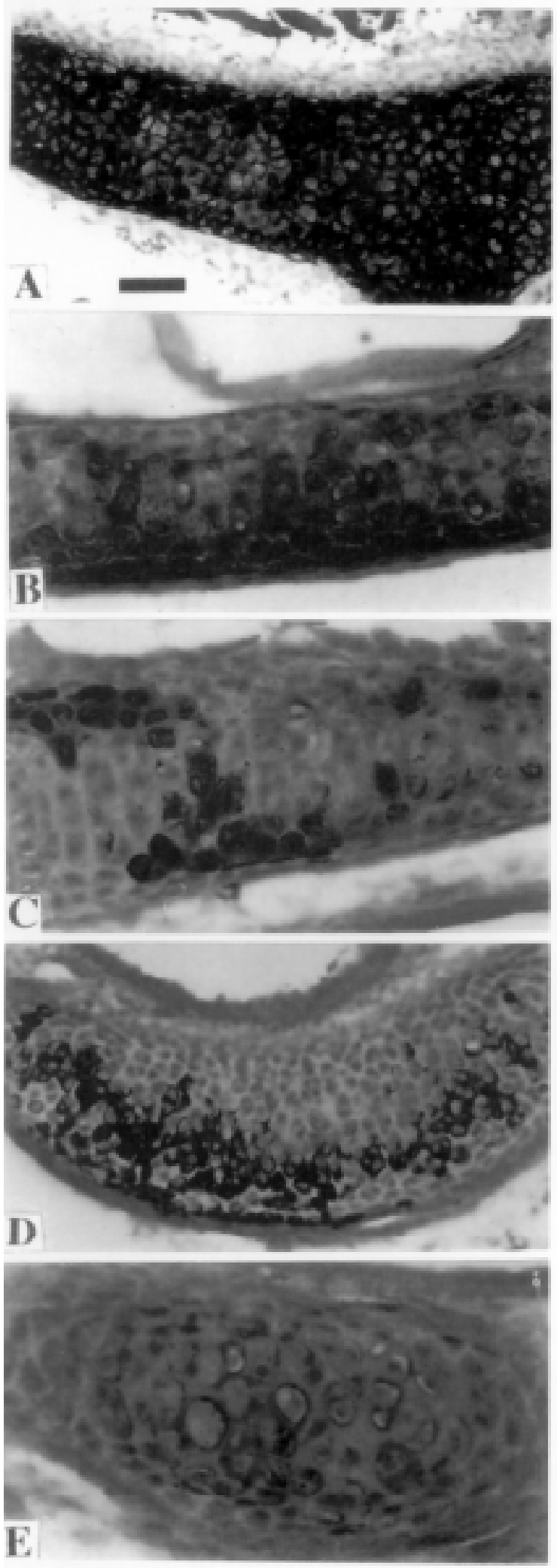
(2000", Figs. 1-5, p. 379). 


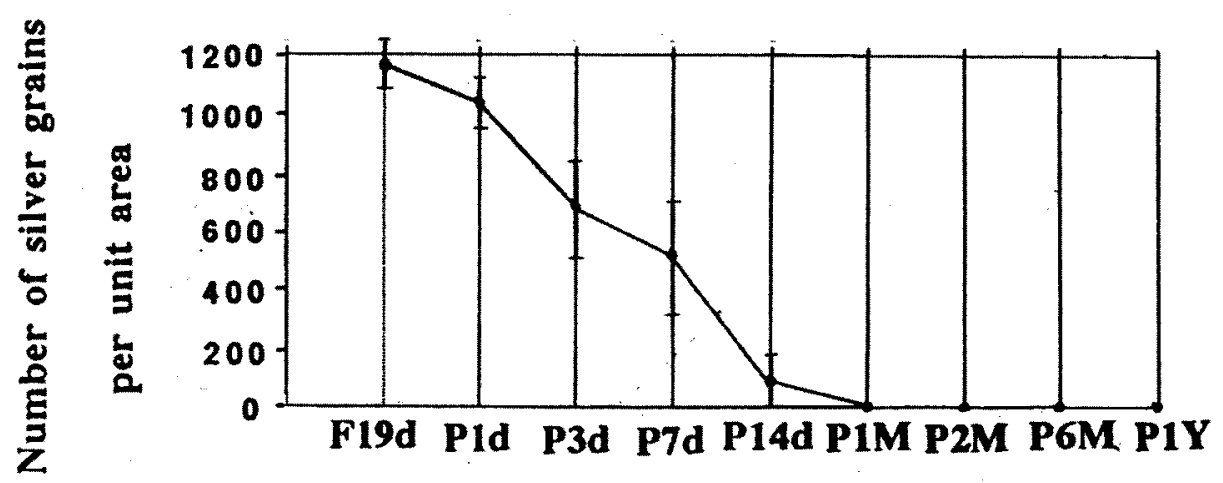

Aging of mice

Flgure 12. Transitional curve of grain counts per unit area $\left(1 \mathrm{~mm}^{2}\right)$, showing radiosulfate incorporations into mouse tracheal cartilage at various ages. Abbreviations to the Fig. F19d=fetal day 19, P1d=postnatal day 1, P3d=postnatal day 3, P7d=postnatal day 7, P14d=postnatal day 14, P1M=postnatal month 1, P2M=postnatal month 2, P6M=postnatal month 6, P1Y=postnatal year 1. From Nagata T (2000, Fig. 6, p. 380).

fetal day 19, while they localized in the outer layer at postnatal day 1, 3 (Fig. 11C) and 7 (Fig. 11D). The number of grains decreased at postnatal day 14 (Fig. 11E) and finally disappeared at postnatal month 1 to 12 . By grain counting, the number of silver grains was the highest at 2 weeks after birth and decreased rapidly after 1 month to 1 year (Fig. 12). These results suggested that the glycoprotein synthesis in the tracheal cartilage was maximum at prenatal stage and decreased from early postnatal days reaching zero at postnatal month 1 . The results accorded well with the aging changes of DNA synthesis of chondrocytes, which decreased from postnatal day 3 to week 1 and month 1 . The results also accorded well with other animals such as rabbits as reported by Boström (1953) who observed incorporations of radiosulfate ${ }^{35} \mathrm{SO}_{4}$ into the tracheal cartilage of young rabbits and as reported by Bélanger (1954) who observed incorporations of ${ }^{35} \mathrm{SO}_{4}$ into the tracheal cartilage of young rats. However, Pelc \& Glückmann (1955) observed incorporation of radiosulfate into the tracheal cartilage, pinna and xyphoid process of 2-3 month old mice after injection of ${ }^{35} \mathrm{SO}_{4}$. They did not observe the perinatal stages when maximal incorporation should be observed. Their observation may be small turnover of glycoproteins after maturation not much synthesis at developmental stages.

\section{Concluding Remarks}

The methods we have developed in our laboratory to demonstrate both soluble and insoluble radioactive compounds by either wet-mounting or dry-mounting radioautography at both light and electron microscopic levels and to quantify macromolecular synthesis or small molecular compounds, preparing many radioautograms at once, were briefly described.

The results from these methods applied to macromolecular syntheses, DNA, RNA, proteins, glycoproteins in respiratory organs, were summarized and reviewed in connection with the aging of animals. 
The results obtained in our laboratory include not only 3-dimensional structures of the organs but also the 4-dimensional features taking the time dimension into account by labeling cells and localizing the sites of incorporation and synthesis in connection with the time lapse and aging of animals. The technologies, which were developed recently, and the results obtained from the applications to various organs should be systematized as a new filed of science designated as radioautography of the organs.

From the results obtained, it is demonstrated that these radioactive precursors were incorporated into various cell types in various organs at various aging groups from perinatal to juvenile, mature and senescent stages showing organ specific patterns of macromolecular synthesis.

\section{Acknowledgments}

The author thanks Mr. Kiyokazu Kametani, Electron Microscopy Laboratory, Shinshu University School of Medicine, for his technical assistance.

\section{References}

Appleton TC. Autoradiography of soluble labeled compounds. J Roy Microsc Soc 1964; 83:277-81.

Bélanger LF. Autoradiographic visualization of the entry and transit of $35 \mathrm{~S}$ in cartilage, bone, and dentin of young rats and the effect of hyaluronidase in vitro. Canad $\mathrm{J}$ Biochem Physiol 1954;32:161-9.

Boström H. Chemical and autoradiographic studies on the sulphate exchange in sulphomucopoly-saccharides. Arkiv Kem 1953;6:43-57.

Christensen AK. Frozen thin sections of fresh tissue for electron microscopy, with a description of pancreas and liver. J Cell Biol 1971;51:772-804.

Cui H. Light microscopic radioautographic study on DNA synthesis of nerve cells in the cerebella of aging mice. Cell Mol Biol 1995;41:1139-54.

Cui H, Gao F, Nagata T. Light microscopic radioautographic study on protein synthesis in perinatal mouse cornea. Acta Histochem Cytochem 2000;33: 31-7.

Duan H, Gao F, Oguchi K, Nagata T. Light and electron microscopic radioautographic study on the incorporation of $3 \mathrm{H}$-thymidine into the lung by means of a new nebulizer. Drug Res 1994;44:880-3.

Gao F, Chen S, Sun L, Kang W, Wang $Z$ and Nagata T. Radioautographic study of the macromolecular synthesis of Leydig cells in aging mice testis. Cell Mol Biol 1995; 41:145-50.

Gao F, Jin C, Ma H, Sun L and Nagata T. Ultra structural and radioautographic studies on DNA synthesis in Leydig cells of aging mouse testis. Cell Mol Biol $1995^{\text {b }}, 41: 151-60$. 
Gao F, Li S, Duan H, Ma H, Nagata T. Electron microscopic radioautography on the DNA synthesis of prenatal and postnatal mice retina after labeled thymidine injection. J Clin Electron Microsc 1992a ${ }^{\mathrm{a}}$ 25:721-2.

Gao F, Ma H, Sun L, Nagata T. Electron microscopic radioautographic study on the nucleic acid and protein synthesis in the aging mouse testis. Med Electron Microsc 1994;27:360-2.

Gao F, Sun L, Chen S, Jin C, Ma H, Nagata T. Radioautographic study on the macromolecular synthesis of Leydig cells in the testis of aging mice. In, Nagata T, editor, Radioautography in Medicine, Shinshu University Press, Matsumoto, Japan, 1993;220-4.

Gao F, Toriyama K, Nagata T. Light microscopic radioautographic study on the DNA synthesis of prenatal and postnatal aging mouse retina after labeled thymidine injection. Cell Mol Biol 1992

Gao F. Study on the macromolecular synthesis in aging mouse seminiferous tubules by light and electron microscopic radioautography. Cell Mol Biol 1993;39:659-72.

Gunarso W, Gao F, Cui H, Ma H, Nagata T. A light and electron microscopic radioautographic study on RNA synthesis in the retina of chick embryo. Acta Histochem 1996;98:309-22.

Gunarso W, Gao F, Nagata T. Development and DNA synthesis in the retina of chick embryo observed by light and electron microscopic radioautography. Cell Mol Biol 1997; 43:189-201.

Hanai T. Light microscopic radioautographic study of DNA synthesis in the kidneys of aging mice. Cell Mol Biol 1993;39:81-91.

Hanai T, Nagata T. Study on the nucleic acid synthesis in the aging mouse kidney by light and electron microscopic radioautography. In: Nagata $T$ (ed.). Radioautography in Medicine. Shinshu University Press, Matsumoto, Japan, 1994a ;pp.209-14,

Hanai T, Nagata T. Electron microscopic study on nucleic acid synthesis in perinatal mouse kidney tissue. Med Electron Microsc 1994' $; 27$ : 355-7.

Hanai T, Usuda N, Morita T, Shimizu T, Nagata T. Proliferative activity in the kidneys of aging mice evaluated by PCNA/cyclin immunohistochemistry. Cell Mol Biol 1993;39:181-91

Hayashi K, Nagata T. Radioautographic study on ${ }^{3} \mathrm{H}$-thymidine incorporation at different stages of muscle development in aging mice. Cell Mol Biol 1993;39:553-60.

Ito $M$. The radioautographic studies on aging change of DNA synthesis and the ultrastructural development of mouse adrenal gland. Cell Mol Biol 1995;42:14-29.

Ito M, Nagata, T. Electron microscopic radioautographic studies on DNA synthesis and ultrastructure of aging mouse adrenal gland. Med Electron Microsc 1996;29:145-52 
Jin C, Nagata T. Light microscopic radioautographic study on DNA synthesis in cecal epithelial cells of aging mice. $J$ Histochem Cytochem $1995^{a} ; 43: 1223-28$.

Jin C, Nagata T. Electron microscopic radioautographic study on DNA synthesis in cecal epithelial cells of aging mice. Med Electron Microsc $1995^{\mathrm{b}} ; 28: 71-5$

Jin C. Study on DNA synthesis of aging mouse colon by light and electron microscopic radioautography. Cell Mol Biol 1995;4:255-68.

Johkura $\mathrm{K}$. The Aging changes of glycoconjugate synthesis in mouse kidney studied by ${ }^{3} \mathrm{H}$-glucosamine radioautography. Acta Histochem Cytochem 1996;29:57-63.

Johkura K, Usuda N, Nagata T. Quantitative study on the aging change of glycoconjugates synthesis in aging mouse kidney. Proc Xth Internat Cong Histochem Cytochem, Acta Histochem Cytochem 1996;29Suppl;507-8.

Kong Y. Electron microscopic radioautographic study on DNA synthesis of the retina and retinal pigment epitheliums of developing mouse embryo. Cell Mol Biol 1992;38:263-72.

Kong Y, Nagata T. Electron microscopic radioautographic study on nucleic acid synthesis of perinatal mouse retina. Med Electron Microsc 1994;27:366-8.

Kong Y, Usuda N, Morita T, Hanai T, Nagata T. Study on RNA synthesis in the retina and retinal pigment epitheliums of mice by light microscopic radioautography. Cell Mol Biol 1992 ; 38:669-78.

Kong Y, Usuda N, Nagata T. Radioautographic study on DNA synthesis of the retina and retinal pigment epitheliums of developing mouse embryo. Cell Mol Biol $1992^{\mathrm{a}} ; 38: 263-72$.

Li S, Gao F, Duan H, Nagata T. Radioautographic study on the uptake of ${ }^{35} \mathrm{SO}_{4}$ in mouse ovary during the estrus cycle. J Clin Electron Microsc 1992;25:709-10.

Li S, Nagata T. Nucleic acid synthesis in the developing mouse ovary, uterus and oviduct studied by light and electron microscopic radioautography. Cell Mol Biol 1995;4:185-95.

Li S. Relationship between cellular DNA synthesis, PCNA expression and sex steroid hormone receptor status in the developing mouse ovary, uterus and oviduct. Histochemistry 1994;102:405-13.

Liang Y. Light microscopic radioautographic study on RNA synthesis in the adrenal glands of aging mice. Acta Histochem 1998;31:203-10.

Liang Y, Ito M, Nagata T. Light and electron microscopic radioautographic studies on RNA synthesis in aging mouse adrenal gland. Acta Anat Nippon 1998;74:291-300.

Ma H, Gao F, Olea MT, Nagata T. Protein synthesis in the livers of aging mice studied by electron microscopic radioautography. Cell Mol Biol 1991;37:607-15

Ma H, Nagata T. Studies on DNA synthesis of aging mice by means of electron microscopic radioautography. J Clin Electron Microsc 1988;21:715-16.

Ma H, Nagata T. Study on RNA synthesis in the livers of aging mice by means of electron microscopic radioautography. Cell Mol Biol 1990;36:589-600. 
Ma H, Nagata T. Collagen and protein synthesis in the livers of aging mice as observed by light and electron microscopic radioautography. Ann Microsc 2000;1:13-22.

Matsumura H, Kobayashi $Y$, Kobayashi $K$, Nagata T. Light microscopic radioautographic study of DNA synthesis in the lung of aging salamander, Hynobius nebulosus. J Histochem Cytochem 1994;42:1004-1004.

Morita, T. Radioautographic study on the aging change of ${ }^{3} \mathrm{H}$-glucosamine uptake in mouse ileum. Cell Mol Biol 1993;39:875-84.

Morita T, Usuda N, Hanai T, Nagata T. Changes of colon epitheliums proliferation due to individual aging with PCNA/cyclin immunostaining comparing with ${ }^{3} \mathrm{H}$ thymidine radioautography. Histochemistry 1993;101:13-20.

Murata F, Momose Y, Yoshida K, Nagata T. Incorporation of ${ }^{3} \mathrm{H}$-thymidine into nuclei of mast cells in adult rat peritoneum. Shinshu Med J 1977;25:72-7.

Murata F, Yoshida K, Ohno S, Nagata T:Ultrastructural and electron microscopic radioautographic study on the mastocytoma cells and mast cells. $J$ Clin Electron Microsc 1978;13:582-3.

Murata F, Yoshida K, Ohno S, Nagata T. Mucosubstances of rabbit granulocytes studied by means of electron microscopic radioautography and X-ray microanalysis. Histochemistry 1979;61:130-50.

Nagata T. Radiolabeling of soluble and insoluble compounds as demonstrated by light and electron microscopy. In: Recent Advances in Cellular and Molecular Biology, Vol. 6. Molecular Biology of Pyridines and DNA, Peroxisomes, Organelles and Cell Movements. Wegmann R. J. and Wegmann M. A. (eds), Peeters Press, Leuven, Belgium, 1992,pp.9-21

Nagata T. Electron microscopic radioautography with cryo-fixation and dry-mounting procedure. Acta Histochem Cytochem 1994;27:471-89.

Nagata T. Light and electron microscopic radioautographic studies on macromolecular synthesis in digestive organs of aging mice. Cell Mol Biol 1995; 41:21-38.

Nagata T. Three-dimensional observation of whole mount cultured cells stained with histochemical reactions by ultrahigh voltage electron microscopy. Cell Mol Biol $1995^{\text {b }}$; $41: 783-92$.

Nagata T. Techniques and application of electron microscopic radioautography. $J$ Electron Microsc 1996;45:258-74.

Nagata T. Techniques and application of microscopic radioautography. Histol Histopathol 1997a; 12:1091-124.

Nagata T. Three-dimensional observation on whole mount cultured cells and thick sections stained with histochemical reactions by high voltage electron microscopy. In: P Motta (ed.). Recent Advances in Microscopy of Cells, Tissues and Organs. Antonio Delfino Editore, Roma, Italy, 1997 ;pp.15-22.

Nagata T. Techniques of radioautography for medical and biological research. Braz $\mathrm{J}$ Med Biol Res 1998; ;31:185-95. 
Nagata T. Radioautographology: the proposal of a new concept. Braz J Med Biol Res $1998^{\mathrm{b}}$;31:977-1018.

Nagata T. Radioautographic studies on DNA synthesis of the bone and skin of aging salamander. Bull Nagano Women's Jr Coll 1998; ;6:1-14.

Nagata T. Study of the effect of aging on macromolecular synthesis in various organ systems using microscopic radioautography. Methods Find Exp Clin Pharmacol 1999;21:683-706.

Nagata T. Light microscopic radioautographic study on radiosulfate incorporation into the tracheal cartilage of aging mice. Acta Histochem Cytochem $2000^{\mathrm{a}} ; 33: 377-83$.

Nagata T. Electron microscopic radioautographic study on the protein synthesis in the pancreas of aging mouse. Bull Nagano Women's Jr Coll 2000 ;8:1-26.

Nagata T, Ito M, Chen S. Aging changes of DNA synthesis in the submandibular glands of mice as observed by light and electron microscopic radioautography. Ann Microsc 2000ª $; 1: 4-12$.

Nagata T, Ito M, Liang Y, Gao F. Study of the effect of aging on macromolecular synthesis in mouse steroid secreting cells using microscopic radioautography. Methods Find Exp Clin Pharmacol 2000' 2 22:5-18.

Nagata T, Kawahara I. Radioautographic study of the synthesis of sulfomucin in digestive organs of mice. J Trace Microprobe Techn 1999;17:339-55.

Nagata T, Morita T, Kawahara I. Radioautographic studies on radiosulfate incorporation in the digestive organs of mice. Histol Histopathol 1999;14:813-20.

Nagata T, Murata F, Electron microscopic dry-mounting radioautography for diffusible compounds by means of ultracryotomy. Histochemistry 1977;54:75-82.

Nagata T, Nawa T. A modification of dry-mounting technique for radioautography of water-soluble compounds. Histochemie 1966;7:370-1.

Nagata T, Nawa T, Yokota S. A new technique for electron microscopic dry-mounting radioautography of soluble compounds. Histochemie 1969;18:241-9.

Nagata T, Usuda N. Studies on the nucleic acid synthesis in pancreatic acinar cells of aging mice by means of electron microscopic radioautography. $\mathrm{J}$ Clin Electron Microsc 1986; 19:486-7.

Nagata T, Usuda $\mathrm{N}$, Ma $\mathrm{H}$ :Electron microscopic radioautography of nucleic acid synthesis in pancreatic acinar cells of prenatal and postnatal aging mice. Proc $\mathrm{XI}^{\text {th }}$ Internat Congr Electron Microsc 1984;3:2281-2.

Nagata T, Usuda N, Ma H. Electron microscopic radioautographic study on lipid synthesis in pancreatic cells of aging mice. $\mathrm{J}$ Clin Electron Microsc 1990;23:841-2.

Nagata T, Usuda N, Maruyama $M$. Electron microscopic radioautographic study on lipid synthesis in perinatal mouse pancreas. J Clin Electron Microsc 1988;21:756-7.

Nagata T, Usuda N, Suzawa $\mathrm{H}$, Kanzawa $\mathrm{M}$. Incorporation of ${ }^{3} \mathrm{H}$-glucosamine into the pancreatic cells of aging mice as demonstrated by electron microscopic radioautography. J Clin Electron Microsc 1992;25:646-7. 
O'Hare KH, Townes PL. Morphogenesis of albino rat lung. An autoradiographic analysis of the embryological origin of the type 1 and 2 pulmonary epithelial cells. J Morphol 1970;132:69-88.

Olea M T, Nagata T. Simultaneous localization of ${ }^{3} \mathrm{H}$-thymidine incorporation and acid phosphatase activity in mouse spleen: Electron microscopic radioautography and cytochemistry. Cell Mol Biol 1992a ; 38:115-22.

Olea M T, Nagata T. A radioautographic study on RNA synthesis in aging mouse spleen after ${ }^{3} \mathrm{H}$-uridine labeling in vitro. Cell Mol Biol $1992^{\mathrm{b}} ; 38: 399-405$.

Pelc SR, Glücksmann A. Sulphate metabolism in the cartilage of the trachea, pinna and xyphoid process of the adult mouse as indicated by autoradiographs. Exp Cell Res 1955;8:336-44.

Sun L. Age-related changes of RNA synthesis in the lungs of aging mice by light and electron microscopic radioautography. Cell Mol Biol 1995;41:1061-72.

Sun L, Gao F, Duan H, Nagata T. Light microscopic radioautography of DNA synthesis in pulmonary cells in aging mice. In, Radioautography in Medicine, Nagata T (editor), Shinshu University Press, Matsumoto, Japan, 1994,pp.201-5.

Sun L, Gao F, Jin C, Duan H, Nagata T. An electron microscopic radioautographic study on the DNA synthesis of pulmonary tissue cells in aging mice. Med Electron Microsc 1995‘ ;28:129-31.

Sun L, Gao F, Jin C, Nagata T. DNA synthesis in the aging mice tracheae by means of light and electron microscopic radioautography. Acta Histochem Cytochem 1997a;30:211-20.

Sun L, Gao F, Nagata T. Study on the DNA synthesis of pulmonary cells in aging mice by light microscopic radioautography. Cell Mol Biol 1995 $;$;1:851-9.

Sun L. Gao F, Nagata T. A light microscopic radioautographic study on protein synthesis in pulmonary cells of aging mice. Acta Histochem Cytochem 1997b; 30:463-70.

Toriyama K. Study on the aging changes of DNA and protein synthesis of bipolar and photo-receptor cells of mouse retina by light and electron microscopic radioautography. Cell Mol Biol 1995;41:593-601.

Yamada A. Timely and topologically defined protein synthesis in the peri-implanting mouse endometrium revealed by light and electron microscopic radioautography. Cell Mol Biol 1993;39:1-12.

Yamada A, Nagata T. Light and electron microscopic radioautography of DNA synthesis in the endometria of pregnant-ovariectomized mice during activation of implantation window. Cell Mol Biol 1992a;38:763-74.

Yamada A, Nagata T. Light and electron microscopic radioautographic studies of RNA synthesis of peri-implanting pregnant mouse uterus during activation of receptivity for blastocyst implantation. Cell Mol Biol 1992 ${ }^{\mathrm{b}}$;38:763-74. 
